Cornell Law Library

Scholarship@Cornell Law: A Digital Repository

Cornell Law Faculty Publications

Faculty Scholarship

$10-1-2012$

\title{
How to Choose the Least Unconstitutional Option: Lessons for the President (and Others) from the Debt Ceiling Standoff
}

Neil H. Buchanan

George Washington University Law School

Michael C. Dorf

Cornell Law School, michaeldorf@cornell.edu

Follow this and additional works at: http://scholarship.law.cornell.edu/facpub

Part of the Constitutional Law Commons, Fourteenth Amendment Commons, Law and Economics Commons, and the Tax Law Commons

\section{Recommended Citation}

Buchanan, Neil H. and Dorf, Michael C., "How to Choose the Least Unconstitutional Option: Lessons for the President (and Others) from the Debt Ceiling Standoff" (2012). Cornell Law Faculty Publications. Paper 591.

http://scholarship.law.cornell.edu/facpub/591

This Article is brought to you for free and open access by the Faculty Scholarship at Scholarship@Cornell Law: A Digital Repository. It has been accepted for inclusion in Cornell Law Faculty Publications by an authorized administrator of Scholarship@Cornell Law: A Digital Repository. For more information, please contact jmp8@cornell.edu. 


\title{
COLUMBIA LAW REVIEW
}

$\begin{array}{lll}\text { VOL. } 112 & \text { OCTOBER } 2012 & \text { NO. } 6\end{array}$

\section{ARTICLES}

\section{HOW TO CHOOSE THE LEAST UNCONSTITUTIONAL OPTION: LESSONS FOR THE PRESIDENT (AND OTHERS) FROM THE DEBT CEILING STANDOFF}

\author{
Neil H. Buchanan* E Michael C. Dorf**
}

The federal statute known as the "debt ceiling" limits total borrowing by the United States. Congress has repeatedly raised the ceiling to authorize necessary borrowing, but a political standoff in 2011 nearly made it impossible to borrow funds to meet obligations that Congress had affirmed earlier that very year. Some commentators urged President Obama to ignore the debt ceiling, while others responded that such borrowing would violate the separation of powers and therefore that the president should refuse to spend appropriated funds.

This Article analyzes the choice the president nearly faced in summer 2011, and which he or a successor may yet face, as a "trilemma" offering three unconstitutional options: ignore the debt ceiling and unilaterally issue new bonds, thus usurping Congress's borrowing power; unilaterally raise taxes, thus usurping Congress's taxing power; or unilaterally cut spending, thus usurping Congress's spending power. We argue that the president should choose the "least unconstitutional" course-here, ignoring the debt ceiling. We argue further, though more tentatively, that if the bond markets would render such debt inadequate to close the gap, the president should unilaterally increase taxes rather than cut spending. We then use the debt ceiling impasse to develop general criteria for political actors to choose among unconstitutional options. We emphasize three principles derived from a famous speech by

* Professor of Law, The George Washington University Law School, and Senior Fellow at the Taxation Law and Policy Research Institute, Monash University.

** Robert S. Stevens Professor of Law, Cornell University Law School. The authors gratefully acknowledge helpful exchanges with and comments from Jack Balkin, Aaron Bruhl, Josh Chafetz, Kevin Clermont, Sherry Colb, Lonny Hoffman, Mitchel Lasser, Martin Lederman, Peter Linzer, Michael McConnell, Alan Morrison, Trevor Morrison, Jens Ohlin, Eduardo Peñalver, Aziz Rana, Neil Siegel, and Laurence Tribe. We also greatly benefited from the questions and comments of student and faculty participants in workshops at Cornell Law School, Duke Law School, and the University of Houston Law School, where we separately presented earlier versions of this Article. Sergio Rudin, Alison Skaife, and Wanling Su provided excellent research assistance. 
President Lincoln: 1) minimize the unconstitutional assumption of power; 2) minimize sub-constitutional harm; and 3) preserve, to the extent possible, the ability of other actors to undo or remedy constitutional violations.

INTRODUCTION 1176

I. The Budget Process, the Debt Ceiling, AND the POLITICAL CRISIS 1182

A. The Annual Federal Budget 1182

B. The Debt Ceiling's Purported Limitation on Borrowing 1183

C. The Applicability or Irrelevance of Section 4 of the Fourteenth Amendment 1188

D. Is the Debt Ceiling Really the Source of the Problem?

II. The PRESIDENT's TRILEMMA: WhiCH Duty Must He IGNORE WHEN HE FACES THREE UNCONSTITUTIONAL CHOICES? 1196

A. Three Powers Reserved to Congress............................... 1197

B. Rules of Interpretation, As Applied to the Debt Ceiling Controversy 1202

C. Practical Issues Raised by Presidential Unilateralism ... 1205 1. When the President Cuts Spending ...................... 1205

2. When the President Increases Borrowing ............. 1208

3. When the President Increases Taxes ..................... 1211

D. Prudential Issues Raised by the President's Choice...... 1213

E. The Hierarchy of Choices ........................................... 1215

III. Beyond the Debt Ceiling: The General Problem of No CONSTITUTIONAL OPTIONS …........................................... 1217

A. The Scope of the Problem ......................................... 1221

B. Minimize the Unconstitutional Assumption of Power.. 1222

C. Minimize Sub-Constitutional Harm 1229

D. Preserve, to the Extent Possible, the Ability To Undo or Remedy Constitutional Violations ............................. 1239

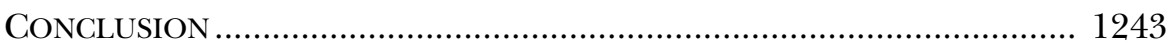

\section{INTRODUCTION}

In the spring of 2011, federal officials announced that, at some point later in the year, the federal government would be unable to meet all of its obligations unless the federal debt ceiling was raised. There was no economic problem. Interest rates on U.S. Treasury bills were close to zero percent, and the government could readily issue new debt to cover 
its expenses, if only Congress would go through the formal process of raising the debt ceiling to conform with the budget that it itself had then only recently approved. ${ }^{1}$ There was a political problem, however. Expressing concern about long-term fiscal deficits, Republicans in Congress-especially those allied with the Tea Party movement-insisted on a dollar of current spending cuts for every dollar increase in the debt ceiling. ${ }^{2}$ Even as Keynesian economists warned of the dangers of premature austerity, Democrats, including President Barack Obama, accepted the Republican view that deficit reduction was imperative, but they insisted that increased tax revenues had to be part of the formula for achieving that goal. ${ }^{3}$ A standoff ensued.

As the day of reckoning approached with no deal in place, some observers advanced a creative solution. Section 4 of the Fourteenth Amendment, they noted, forbids the questioning of " $\mathrm{t}]$ he validity of the public debt of the United States," ${ }^{4}$ and therefore, they argued, the debt ceiling is unconstitutional insofar as it forbids the federal government from honoring its existing financial commitments. ${ }^{5}$ Accordingly, these observers contended that in the event that Congress and the President failed to reach an agreement, the President would be authorized, or perhaps even constitutionally obligated, to simply ignore the debt ceiling. ${ }^{6}$ This proposed gambit was quickly dubbed the "nuclear option," and it garnered support from some prominent politicians, including former President Bill Clinton. ${ }^{8}$

1. See Department of Defense and Full-Year Continuing Appropriations Act, 2011, Pub. L. No. 112-10, 125 Stat. 38.

2. See Alan Silverleib \& Tom Cohen, Latest Deficit Talks End with a Tense Exchange, CNN (July 13, 2011), http://articles.cnn.com/2011-07-13/politics/debt.talks_1_debtceiling-short-term-extension-debt-ceiling-hike (on file with the Columbia Law Review) (outlining evolving brinksmanship between very conservative Republicans and President in debt ceiling debate).

3. Id.

4. U.S. Const. amend. XIV, $\S 4$.

5. See Elspeth Reeve, Is the Debt Ceiling Unconstitutional?, Atlantic Wire (June 29, 2011), http://www.theatlanticwire.com/politics/2011/06/debt-ceiling-unconstitutional/ 39408/ (on file with the Columbia Law Review) (summarizing and excerpting legal reasoning in support of presidential authority to disregard debt ceiling on grounds it is unconstitutional).

6. Id.

7. E.g., Aaron Blake, Obama Won't Find Safe Harbor in 14th Amendment, The Fix, Wash. Post (July 29, 2011, 12:44 PM), http://www.washingtonpost.com/blogs/the-fix/ post/why-the-14th-amendment-is-not-a-good-option-for-obama/2011/07/29/gIQAynPOhI _blog.html (on file with the Columbia Law Review).

8. See Joe Conason, Exclusive Bill Clinton Interview: I Would Use Constitutional Option To Raise Debt Ceiling and "Force the Courts To Stop Me," Nat'l Memo (June 19, 2011, 4:03 AM), http://www.nationalmemo.com/exclusive-former-president-bill-clintonsays-he-would-use-constitutional-option-raise-debt (on file with the Columbia Law Review) 
The nuclear option had its own problems, however. For one thing, it could backfire. As a hedge against the possibility that the government would later default on debt issued by a president acting without congressional authorization, bond purchasers might demand very high rates of interest for the "radioactive" bonds, thus destabilizing rather than calming financial markets. ${ }^{9}$ But even if the president's unilateral authorization of new debt would pacify the markets, it would apparently avoid a violation of Section 4 of the Fourteenth Amendment only by violating the separation of powers. ${ }^{10}$ After all, Article I of the United States Constitution gives to Congress, not the president, the power " $[t]$ o borrow Money on the credit of the United States."11

Thus, Treasury Secretary Timothy Geithner quickly announced that the Administration would not rely on the Section 4 nuclear option. ${ }^{12}$ Perhaps that was simply a ploy to increase pressure on Congress to strike a deal. If so, it worked, because at the eleventh hour Congress did indeed pass legislation raising the debt ceiling and punting to a newly created bipartisan congressional "super-committee" the question of how to achieve the deficit reduction that was also mandated by the legislation. ${ }^{13}$ The super-committee failed to send a legislative proposal to Congress for consideration, so as this Article goes to press, automatic spending cuts are slated to occur unless Congress enacts superseding legislation. ${ }^{14}$

(comparing former President Clinton's own budget battle experiences to President Obama's and reporting Clinton's belief that Obama should raise debt ceiling unilaterally).

9. Cf. Bruce Bartlett, The Debt Limit Options President Obama Can Use, Fiscal Times (Apr. 29, 2011), http://www.thefiscaltimes.com/Columns/2011/04/29/The-DebtLimit-Option-President-Obama-Can-Use.aspx (on file with the Columbia Law Review) (noting rapid turnover of three-month Treasury bills should quickly resolve these fears and limit impact of problem).

10. See Laurence H. Tribe, A Ceiling We Can't Wish Away, N.Y. Times, July 8, 2011, at A23 [hereinafter Tribe, Ceiling We Can't Wish Away] (arguing Fourteenth Amendment does not authorize president to exercise legislative power to prevent constitutional violations).

11. U.S. Const. art. I, § 8, cl. 2; see Tribe, Ceiling We Can’t Wish Away, supra note 10 (describing allocation of borrowing power to Congress).

12. See This Week (ABC television broadcast July 24, 2011), available at http://abcnews.go.com/Politics/week-transcript-timothy-geithner/story?id=14147682

(transcript on file with the Columbia Law Review) (indicating administration had decided after careful review that nuclear option was not workable solution); see also Letter from George W. Madison, Gen. Counsel, Treasury Dep't, to N.Y. Times (July 8, 2011), available at http://www.treasury.gov/connect/blog/Pages/Fact-Check-Treasury-General-CounselGeorge-Madison-Responds-to-New-York-Times-Op-Ed-on-14th-Amendment.aspx (on file with the Columbia Law Review) (explaining Secretary Geithner had "always viewed the debt limit as a binding legal constraint that can only be raised by Congress").

13. See Budget Control Act of 2011, Pub. L. No. 112-25, § 401, 125 Stat. 240, 259-63 (establishing Joint Select Committee on Deficit Reduction to recommend legislation that would reduce deficit by $\$ 1.5$ trillion by 2021).

14. Id. $\$ 302$, 125 Stat. at 256-59. Some members of Congress have indicated that they wish to repeal the scheduled cuts. E.g., 158 Cong. Rec. H3072 (daily ed. May 17, 
The foregoing events will likely have important political and economic implications, but this Article focuses mostly on the constitutional questions that were raised in the days and weeks before Congress reached its crisis-delaying deal in August 2011. With influential members of Congress-including both the Speaker of the House and the Senate Minority Leader-having indicated that they intend to use the debt ceiling as leverage in future battles over fiscal policy, ${ }^{15}$ a replay of the debt ceiling standoff remains a very live possibility. Moreover, the summer 2011 crisis raised an important, but mostly unrecognized, issue in constitutional law more generally: What should government officials do when all of their options are unconstitutional? This Article uses the $2011 \mathrm{debt}$ ceiling crisis as a case study to begin to explore that question.

Under a plausible description of the options President Obama would have faced had Congress failed to strike a debt ceiling deal in August 2011, every realistic option open to him would have violated some constitutional provision: Failure to pay bondholders, contractors, employees, and other persons entitled to money under federal law would have violated Section 4 of the Fourteenth Amendment and, in addition, the President's obligation to "take Care that the Laws" creating the relevant obligations "be faithfully executed", ${ }^{16}$ issuing new debt without congressional authorization would have violated the separation of powers; so too would have other unilateral actions to increase government revenue, such as a presidential decree raising taxes or a presidential sale of government property without congressional authorization; ${ }^{17}$ and simply printing additional dollars and crediting them to the government's account would have violated the federal statute that limits the amount of money in circulation, ${ }^{18}$ along with the power reserved to Congress to coin money and regulate the value thereof, ${ }^{19}$ and thus could have been said to violate the separation of powers and the Take Care Clause as well.

To be sure, legitimate arguments can be made for the conclusion that President Obama would have had some constitutional options even

2012) (statement of Rep. Scott Rigell) ("Sequestration is not a rational course correction, but instead it is a violent, sudden, and severe budget cut, the adverse consequences of which cannot be overstated.”); 158 Cong. Rec. H2604 (daily ed. May 10, 2012) (statement of Rep. Howard McKeon) ("I rise today in strong support of [repealing the scheduled cuts].").

15. See infra notes 60-61 and accompanying text (discussing statements of Senate Minority Leader Mitch McConnell and House Speaker John Boehner).

16. U.S. Const. art. II, $\S 3$.

17. See id. art. IV, $\S 3$, cl. 2 ("The Congress shall have Power to dispose of and make all needful Rules and Regulations respecting the Territory or other Property belonging to the United States ....").

18. See 31 U.S.C $\$ 5115$ (b) (2006) ("The amount of United States currency notes outstanding and in circulation ... may not be more than $\$ 300,000,000 \ldots$. . ).

19. U.S. Const. art. I, $\S 8, \mathrm{cl} .5$. 
if Congress had not acted in August 2011. Some commentators argue that Section 4 of the Fourteenth Amendment only bars a limited category of defaults-failures to pay bondholders (but not other obligees, for example, Social Security recipients), in one view, ${ }^{20}$ or more narrowly still, only failures to pay principal (but not interest) on federal bonds. ${ }^{21}$ Other commentators have advanced exotic solutions, such as Professor Jack Balkin's arresting suggestion that the United States could mint two onetrillion-dollar platinum coins, or sell to the Federal Reserve an "exploding option" to purchase government property for two trillion dollars, and then keep the money (credited to the government's account by the Federal Reserve) after the option expires (or explodes). ${ }^{22}$ We explore these and related exotica below ${ }^{23}$ because they help contextualize the issue, but our analysis suggests that the President's only realistic options were all unconstitutional. ${ }^{24}$ At a minimum, we are willing to assume that

20. See Michael Abramowicz, Beyond Balanced Budgets, Fourteenth Amendment Style, 33 Tulsa L.J. 561, 580-89 (1997) [hereinafter Abramowicz, Beyond Balanced Budgets] (arguing "public debt" in Section 4 of Fourteenth Amendment encompasses only financial obligations stemming from agreements and Social Security is not such a financial obligation); Michael Abramowicz, Train Wrecks, Budget Deficits, and the Entitlements Explosion: Exploring the Implications of the Fourteenth Amendment's Public Debt Clause 43-45 (George Wash. Univ. Law Sch. Pub. Law \& Legal Theory Paper No. 575, 2011) [hereinafter Abramowicz, Train Wrecks], available at http://papers.ssrn. com/abstract=1874746 (on file with the Columbia Law Review) (same); John Berlau, Constitutional Nonsense on Debt, Nat'l Rev. Online (July 8, 2011, 12:00 PM), www.nationalreview.com/articles/271329/constitutional-nonsense-debt-john-berlau (on file with the Columbia Law Review) (arguing "public debt" does not include government benefits).

21. Cf. Garrett Epps, Our National Debt "Shall Not Be Questioned," the Constitution Says, Atlantic (May 4, 2011, 7:00 AM), http://www.theatlantic.com/politics/archive/2011/ 05/our-national-debt-shall-not-be-questioned-the-constitution-says/238269/ (on file with the Columbia Law Review) (noting perhaps only outright repudiation of obligations, but not temporary default or delay in payment, is barred); Michael Stern, "Threatening Default": A Response to Professor Balkin, Point Ord. (July 1, 2011, 6:04 PM), http://www.pointoforder.com/2011/07/01/threatening-default-a-response-to-professorbalkin/ (on file with the Columbia Law Review) (arguing only outright repudiation of public debt violates Section 4 of Fourteenth Amendment).

22. See Jack M. Balkin, 3 Ways Obama Could Bypass Congress, CNN (July 28, 2011), http://articles.cnn.com/2011-07-28/opinion/balkin.obama.options_1_debt-ceiling-

congress-coins [hereinafter Balkin, Ways to Bypass] (on file with the Columbia Law Review). Because 31 U.S.C. $\$ 5112(\mathrm{k})$ grants the Secretary of the Treasury the discretion over the denomination and issuance of platinum bullion coins, it could arguably be used to circumvent the statutory limit on currency notes.

23. See infra Part III.C.

24. We do not directly consider the proposal of Professors Eric Posner and Adrian Vermeule, under which the President could simply issue new debt pursuant to his supposed "paramount duty to ward off serious threats to the constitutional and economic system." Eric A. Posner \& Adrian Vermeule, Obama Should Raise the Debt Ceiling on His Own, The Opinion Pages, N.Y. Times (July 22, 2011), http://www.nytimes.com/2011/07/ 22/opinion/22posner.html (on file with the Columbia Law Review). Posner and Vermeule do not attempt to tie this duty to any particular constitutional text. Indeed, in their view, 
that is true. If it turns out not to have been true in 2011, it may well be true in future crises.

The Article proceeds in four Parts. Part I describes in greater detail the nature of the options that confronted President Obama in the summer of 2011. It elaborates on an exchange of views between Professor Laurence Tribe and one of the current authors, which first appeared in essays in The New York Times, ${ }^{25}$ the online magazine Verdict, ${ }^{26}$ and the eponymous blog of the other of the current authors, ${ }^{27}$ to show that the real issue was not whether the debt ceiling statute violated Section 4 of the Fourteenth Amendment, but which unconstitutional option the President ought to have chosen had the day of reckoning arrived.

Part II answers that question. For simplicity, we focus on three options and rank them from worst to least bad. We conclude that the nuclear option would have been the President's least bad option. Readers may be surprised at our further conclusion. We tentatively suggest that a unilateral tax increase by the President comes in second place, less bad than the option that the President and nearly every other politician appeared to favor: unilateral spending cuts.

Part III draws general lessons about how the President and other government officials should choose among unconstitutional options. We

the very effort to constrain authority by law in emergencies is in vain. See Eric A. Posner \& Adrian Vermeule, The Executive Unbound: After the Madisonian Republic 90-93 (2010) (characterizing actual workings of American administrative law as exemplifying theory of Carl Schmitt). Although we reach the same conclusion as Posner and Vermeule about the best course of action for the President, we do not endorse their view that emergencies provide extralegal justifications. Indeed, our premise is more nearly the opposite: We argue that even when the president has no lawful options, his decisions are constrained by law.

25. See Tribe, Ceiling We Can't Wish Away, supra note 10.

26. See Neil H. Buchanan, The Debt Ceiling Law Is Unconstitutional: A Reply to Professor Tribe, Verdict (July 11, 2011), http://verdict.justia.com/2011/07/11/the-debtceiling-law-is-unconstitutional (on file with the Columbia Law Review) (disagreeing with Professor Tribe's view that debt ceiling's unconstitutionality would leave President unable to provide remedy); see also Neil H. Buchanan, The Debt-Limit Crisis: A Problem That Will Keep Coming Back Unless President Obama Takes a Constitutional Stand Now, Verdict (July 7, 2011), http://verdict.justia.com/2011/07/07/the-debt-limit-crisis (on file with the Columbia Law Review) (arguing that debt limit is dangerous policy and that results of default by federal government would be catastrophic).

27. See, e.g., Laurence Tribe, Professor Tribe Replies to Professor Buchanan Replying to Professor Tribe Replying to ...., Dorf on L. (July 21, 2011, 12:20 AM), http://www.dorfonlaw.org/2011/07/professor-tribe-replies-to-professor.html (on file with the Columbia Law Review) (replying to Buchanan and arguing debt ceiling only creates crisis in combination with other acts of Congress). The Article also builds on some observations that first appeared in Michael C. Dorf, The Debt Ceiling Crisis Reveals a Constitutional Gap: How To Choose Among Unconstitutional Options, Verdict (Aug. 1, 2011), http://verdict.justia.com/2011/08/01/the-debt-ceiling-crisis-reveals-a-constitution al-gap (on file with the Columbia Law Review) (arguing American legal precedents and tradition provide scant guidance for actors facing choice among unconstitutional options). 
contend that the task of a government official in choosing among unconstitutional options is to choose the "least unconstitutional" one, rather than simply to make a policy choice. Policy considerations inevitably inform the analysis of what counts as least unconstitutional, in part because the Constitution itself nowhere allows that government officials may sometimes be required to disobey one or more of its provisions in order to satisfy one or more other provisions. Nonetheless, the decision whether to violate one constitutional provision rather than another (or to violate a single provision in one way rather than another) is not, in our view, to be decided by an all-things-considered policy judgment. Instead, as we explain at greater length in Part III, distinctively constitutional policies-such as preservation of the balance of powers among the branches-should be given extra weight in a calculus that also gives some weight to sub-constitutional policies. We provide guidelines that build upon President Lincoln's famous "all the laws, but one" speech. ${ }^{28}$ Part III also explores whether the least unconstitutional option ought, in virtue of that fact, to be deemed constitutional. We ultimately disapprove of such post hoc relabeling because it risks obscuring real conflicts among constitutional requirements and values.

\section{The Budget Process, the DebT Ceiling, AND the Political Crisis}

To understand the nature of the choices President Obama nearly faced in the summer of 2011, and the choices that a future president could face should the crisis recur, this Part begins by placing the budget standoff in context. In this Part, we show how the debt ceiling operates in tandem with a larger web of statutory and constitutional constraints on presidential action.

\section{A. The Annual Federal Budget}

The federal government of the United States is funded on an annual cycle, with the political branches engaged each year in a process that plays a large role in determining the levels of spending and tax collection that the government may undertake. ${ }^{29}$ Those policy decisions-in combination with other, longer-term policy decisions-determine who receives various benefits and who bears certain burdens as a result of the various programs and activities funded and operated by the federal government and the means by which funds to finance the government are collected. ${ }^{30}$

28. See infra text accompanying notes 156-163.

29. See generally 31 U.S.C. $§ 1105$ (2006) (detailing requirements for yearly budget submitted by president).

30. Annual decisions only partly determine spending and taxing levels, because most spending-so-called "entitlements," interest on the national debt, and other "mandatory" spending - as well as most of the tax code is enacted in statutes that remain in force from year to year. See, e.g., 42 U.S.C. $\$ 401$ (a)-(b) (2006) (appropriating funds collected out of various income taxes to Federal Old-Age and Survivors Insurance Trust Fund as well as 
Taken together, the short-term and long-term policies also shape, to a very important degree, the level and nature of economic activity at any given time, as well as the likely path of future economic growth, the extent of environmental harms and remediation, the provision of education at all levels, and myriad other variables that affect the lives of current and future citizens.

The budget process is, therefore, political in every sense of the word. Federal budgetary decisions matter deeply in the day-to-day lives of people, and they often determine the political fates of members of Congress and presidents. ${ }^{31}$ And as the political culture has become less cooperative over the past few decades, the budgetary process has come under increasing strain. ${ }^{32}$ It is thus increasingly likely that we will soon enter uncharted territory, with budgetary gridlock forcing the president to take actions that test constitutional limits.

\section{B. The Debt Ceiling's Purported Limitation on Borrowing}

The annual federal budget authorizes government agencies to carry out functions that require the expenditure of funds..$^{33}$ When a budget is passed, the Treasury Department is authorized to issue funds under the federal government's array of programs and contracts. ${ }^{34}$ The budget must include both the authority to undertake specific activities (to build bridges, to pay medical benefits, and so on) and the appropriation of money to spend on those activities. ${ }^{35}$ The final appropriations bills thus provide the legal authority to take money that is in the federal government's possession and spend it on authorized programs.

The money in the government's possession at any moment includes revenues collected from taxation and other sources (such as various

Federal Disability Insurance Trust Fund); see also Josh Chafetz, Congress's Constitution, 160 U. Pa. L. Rev. 715, 729 (2012) (noting in 2010 fiscal year, sixty-one percent of federal spending was mandatory spending, and percentage has been increasing over time). Of course, Congress could exert more annual control over spending by replacing entitlement formulae with annual appropriations. See id. (characterizing entitlement provisions as "ced[ing] the institutional advantage of annual appropriations" to president).

31. See Allen Schick, The Federal Budget: Politics, Policy, Process 3 (3d ed. 2007) ("In national politics, it is now the age of budgeting.").

32. Id. at 2-4, 108-10 (noting increased political gridlock as federal budget grew).

33. Generally, federal agencies cannot use funds until they have been appropriated, via the yearly budget or some other statutory authorization. See 31 U.S.C. $§ 1347$ ("An agency in existence for more than one year may not use amounts otherwise available for obligation to pay its expenses without a specific appropriation or specific authorization by law.").

34. See id. §321(a)(3) ("The Secretary of the Treasury shall ... issue warrants for money drawn on the Treasury consistent with appropriations ....").

35. Id. § 1105 (a) (12)-(22). 
fees) ${ }^{36}$ If the money available at any given moment is inadequate to fund the appropriated programs, the law authorizes the Treasury to borrow funds sufficient to cover the shortfall. ${ }^{37}$ If the current levels of appropriated spending fall short of annual revenues (that is, if the government runs a surplus), the remaining funds are used to repay previously issued debt obligations as those debt obligations come due. ${ }^{38}$

Therefore, together with mandatory spending, ${ }^{39}$ each year's budget process implies a change in the overall level of outstanding federal debt. ${ }^{40}$ If appropriated spending exceeds authorized taxes, the Treasury is instructed to borrow more money, under Congress's Article I power to borrow money on the credit of the United States. ${ }^{41}$ This instruction includes borrowing any funds necessary to repay the principal and interest on the debt obligations from previous years that have come due, allowing the aggregate level of debt to rise even while the federal government honors its contractual commitments to its creditors. ${ }^{42}$

The annual change in the aggregate level of the federal government's debt, therefore, is necessarily determined by the difference between spending and tax revenues authorized in the budget. ${ }^{43}$ If, for example, the total debt is ten trillion dollars at the beginning of the fiscal year, and spending appropriations exceed tax revenues by one trillion dollars during the fiscal year, then the debt will go up to eleven trillion dollars (putting aside daily compounding of interest and similar factors). The budget itself both determines the necessary change in aggregate borrowing and authorizes any new borrowing that is required to carry out the will of Congress, as expressed in its duly enacted budget.

36. See id. $\$ 3302$ (b) (requiring deposit of all public funds into Treasury); id. $\$ 3720$ (requiring money collected by other agencies to be deposited with Treasury). For an example of the various fees collected by the Treasury, see the Freedom of Information Act (FOIA) fee schedule detailed by 31 C.F.R. $\$ 1.7$ (2012) (outlining four categories of FOIA requesters and defining fees and fee waiver provisions).

37. See, e.g., 31 U.S.C. \$ 3104(a) ("The Secretary of the Treasury may borrow on the credit of the United States Government amounts necessary for expenditures authorized by law....”); id. \$3102(a) (allowing Treasury Secretary to issue bonds); id. §3103(a) (allowing Treasury Secretary to issue notes).

38. Net repayment of debt last occurred during the late Clinton administration, as the public debt shrank from $\$ 3,772.3$ billion in 1997 to $\$ 3,319.6$ billion in 2001. Cong. Budget Office, The Budget and Economic Outlook: Fiscal Years 2010 to 2020, at 126 (2010), available at http://www.cbo.gov/doc.cfm?index=10871\&type=1 (on file with the Columbia Law Review).

39. See supra note 30 .

40. Reflecting this reality, every federal budget must include an up-to-date report to Congress on the level of federal debt. 31 U.S.C. $\$ 1105$ (a) (10), (36).

41. See supra note 37 .

42. See 31 U.S.C. $\$ 3111$ (allowing Treasury to issue new obligations in order to redeem or refund outstanding bonds, notes, bills, and certificates).

43. See, e.g., Jacqueline Murray Brux, Economic Issues and Policy 393 (5th ed. 2010) (defining "national debt"). 
Accordingly, there has always been an unofficial "debt ceiling." That is, when Congress and the president determine the levels of spending and revenues, they also necessarily determine the path of the national debt. The debt will be as high as Congress permits, and no higher. Various agencies of the federal government issue estimates of how any budget will change the aggregate level of debt, providing that information to Congress, the president, and the public as part of the negotiations over each year's budget choices. ${ }^{44}$ Subject to unexpected changes in the economic conditions that can alter tax revenues or require different levels of expenditures,${ }^{45}$ the passage of a new budget is necessarily a statement that the government is planning to owe a certain amount of money at any given time.

Even though the budget process itself is both necessary and sufficient to empower Congress to limit the government's debt, the total level of debt has become a politically salient (albeit highly inaccurate) measure of the government's "fiscal responsibility." 46 As the national debt level has risen over time, politicians and the public have expressed concern that this trend might harm the economy, now or in the future. ${ }^{47}$ This concern is often manifested in claims that the debt level is impoverishing "our children and grandchildren," ${ }^{8}$ who will purportedly bear the

44. See 31 U.S.C. $§ 1105$ (a) (21)(B) (requiring president to submit to Congress budget showing "specific aspects of the program of, and appropriations for, each agency"); id. $\$ 1105(\mathrm{a})(21)(\mathrm{C})$ (requiring this budget to include estimated goals and financial requirements). For an example of such a published estimate, see Office of Mgmt. \& Budget, Analytical Perspectives: Fiscal Year 2012 Budget of the U.S. Government 115-18 (2012) [hereinafter OMB, Analytical Perspectives], available at http://www.whitehouse .gov/sites/default/files/omb/budget/fy2012/assets/spec.pdf (on file with the Columbia Law Review).

45. See, e.g., OMB, Analytical Perspectives, supra note 44, at 119 ("During the budget execution phase, the Government sometimes finds that it needs more funding than the Congress has appropriated for the fiscal year because of unanticipated circumstances.").

46. See, e.g., 157 Cong. Rec. H5854-55 (daily ed. Aug. 1, 2011) (statement of Rep. Tom Reed) ("Mr. Speaker, \$14.4 trillion; \$1.6 trillion every year added onto that national debt. The people in November, 2010, spoke loudly.... They want us to get our fiscal house in order."); 157 Cong. Rec. H5678 (daily ed. July 28, 2011) (statement of Rep. Jerry McNerney) ("Democrats and Republicans agree that raising the Federal debt is unsustainable, that the default is absolutely unacceptable, and that we must set our country on a course of fiscal responsibility.").

47. See, e.g., Pew Research Ctr. for the People \& the Press, Frustration with Congress Could Hurt Republican Incumbents 17 (2011), available at http://www.people-press.org/ files/legacy-pdf/12-15-11\%20Congress\%20and\%20Economy\%20release.pdf (on file with the Columbia Law Review) (finding seventy-six percent of respondents believe debt is "major threat" to national economy).

48. See, e.g., 175 Cong. Rec. H7637 (daily ed. Nov. 16, 2011) (statement of Rep. Michael McCaul) ("Our debt burden in this country is so heavy, it is no longer simply a financial issue; it is a moral issue. We have spent and spent, racking up astronomical debt that will dampen the American Dream for our children and grandchildren."). 
burdens of the nation's debt yet receive none of the benefits of the activities that gave rise to the debt. ${ }^{49}$

In the face of concerns that the debt might be rising in an uncontrolled fashion-even though, as noted, Congress maintains complete control over the level and path of federal debt-Congress began in the early twentieth century to impose a purported limit on total federal debt. Originally enacted in 1917,,$^{50}$ and imposed in its current form beginning in $1939,{ }^{51}$ the debt ceiling law imposes an upper limit on the face amount of debt that the U.S. government can owe at any time. ${ }^{52}$

This limit is, however, calculated in a peculiar fashion. It includes in the total measure of the debt owed by the federal government the value of loans that the federal government has made to itself. ${ }^{53}$ That is, when the government's internal accounts treat interagency obligations as "government borrowing" (without noting that the government is also lending the money), then that accounting convention increases the debt of the United States, as defined by the debt ceiling statute..$^{54}$ Moreover, with the economy growing over time, the government's ability to finance its obligations improves as well. The debt ceiling, however, is denomi-

49. This is a grossly inaccurate view of the underlying reality, in no small part because money borrowed today may be put to productive use that will benefit those very children and grandchildren. For example, the government may purchase land they can use for recreation or pay teachers to educate them. But this is not the place for us to argue against the view that the government faces a long-term fiscal crisis or to suggest that even if such a crisis looms, efforts to redress it should be delayed until a period of sustained economic growth. For further discussion of these issues, see generally Neil H. Buchanan, Good Deficits: Protecting the Public Interest from Deficit Hysteria, 31 Va. Tax Rev. 75 (2011) (arguing many deficit fears are unfounded and proposing establishment of independent agency to identify spending projects that warrant debt financing); Neil H. Buchanan, What Do We Owe Future Generations?, 77 Geo. Wash. L. Rev. 1237 (2009) (arguing that likely higher living standards of future generations undercut claim that current public debt unfairly disadvantages such future generations). The salient point here is that the widespread perception of the need for deficit reduction has been lately driving federal budgetary priorities.

50. Second Liberty Bond Act of 1917, Pub. L. No. 65-43, 40 Stat. 288.

51. Amendment to Second Liberty Bond Act, Pub. L. No. 76-201, 53 Stat. 1071 (1939); see also D. Andrew Austin \& Mindy R. Levit, Cong. Research Serv., RL 31967, The Debt Limit: History and Recent Increases 3 (2011) (describing history of debt ceiling, including 1939 changes that created aggregate ceiling of all government debt).

52. 31 U.S.C. $\$ 3101$ (2006).

53. See Schick, supra note 31, at 124.

54. This is not an insignificant sum. At the end of fiscal year 2011, gross federal debt was approximately $\$ 14.8$ trillion, while the debt actually held by the public (which includes all lenders, foreign and domestic, as well as the Federal Reserve System, but not interagency debt within the federal government) was approximately $\$ 8.5$ trillion. U.S. Federal Debt by Year, USGovernmentSpending.com (Aug. 3, 2012), http://www.us governmentspending.com/federal_debt (on file with the Columbia Law Review). The difference-more than one-third of gross debt—was mostly the internal obligations in the Social Security Trust Funds. See Dep't of the Treasury Fin. Mgmt. Serv., Treasury Bull., June 2012, at 21 tbl.FD-1 (detailing debt totals and holders for fiscal year 2011). 
nated in dollars, rather than as a percentage of national income,$^{55}$ which effectively lowers the debt ceiling over time, unless Congress acts to increase it. ${ }^{56}$

As history has unfolded in the years since the debt ceiling statute was first enacted, Congress has generally acted to increase the debt ceiling as necessary, in line with the new accumulated borrowing needs implied by annual budgets. ${ }^{57}$ Prior to 2011, there were brief political standoffs over proposed increases in the debt ceiling, with Congresses under the control of one political party using the debt ceiling vote to try to extract concessions from a president of the opposite party-or simply using the debt ceiling vote ${ }^{58}$ as a moment to make speeches about fiscal responsibility. ${ }^{59}$ While these standoffs have arisen occasionally over the decades, the mid-2011 political crisis was the first time that it appeared that Congress might simply refuse to increase the debt ceiling, even though its own budget required more borrowing to fund its required spending levels, given its decisions about tax revenues and other laws on the books.

Although that crisis was ultimately defused, the Minority Leader in the United States Senate subsequently announced that the debt ceiling would henceforth become a weapon in budget negotiations. ${ }^{60}$ The Speaker of the House endorsed continued debt-ceiling brinksmanship in

55. See 31 U.S.C. $\$ 3101$ (b) ("The face amount of obligations issued under this chapter and the face amount of obligations whose principal and interest are guaranteed by the United States Government (except guaranteed obligations held by the Secretary of the Treasury), may not be more than $\$ 14,294,000,000,000$, outstanding at one time ....").

56 . To be clear, even denominating a debt limit in percentage-of-GDP terms could have perverse consequences, under certain circumstances. During a recession, for example, GDP falls (by definition). If the debt were limited to a fixed percentage of GDP, the debt limit statute would affirmatively require the president to decrease spending or raise taxes in the teeth of the recession. This would mean that a percentage-of-GDP limit could force decisions that would actively reinforce the negative trend of the economy. Although we do not endorse a debt limit statute in any form, we do note that expressing a debt limit as a percentage of the economy's potential GDP would avoid this problem, because potential GDP generally is invariant to short-term recessionary fluctuations in the economy.

57. See Austin \& Levit, supra note 51, at 15 tbl.2 (listing increases in debt limit since 1993).

58. See id. at 12-15 (discussing process of raising debt ceiling from 2008 to 2010).

59. See, e.g., 148 Cong. Rec. 8718 (2002) (statement of Rep. Jim Turner) ("The statutory debt ceiling is a law that provides the maximum amount that our Federal Government can go into debt. It is one of the few tools that we have to promote fiscal responsibility and require fiscal discipline in this House.").

60. See 157 Cong. Rec. S5219 (daily ed. Aug. 2, 2011) (statement of Sen. Mitch McConnell) ("[N]ever again will any President, from either party, be allowed to raise the debt ceiling... without having to engage in the kind of debate we have just come through."). 
May 2012. ${ }^{61}$ No longer will disagreements over spending, taxes, and borrowing be worked out only through the budget process itself, with Congress then agreeing to raise the debt ceiling to comport with the projected increase in debt that its own decisions require. Congress (or, under certain circumstances, a blocking minority of the Senate) might in the future refuse to increase the debt limit, engaging in political brinksmanship to extract concessions on policy from the other party's leadership. Such maneuvers differ from the brinksmanship in normal budget negotiations, where members of Congress can block the government from agreeing to future obligations, because a refusal to increase the debt ceiling makes it impossible for the government to honor its current obligations, to which it committed when it passed its budget.

Furthermore, although the most recent debt ceiling standoff was focused on federal spending itself-with newly authorized increases in borrowing tied to future decreases in spending by the federal government ${ }^{62}$ - there is nothing to prevent the debt ceiling from being held hostage to non-budgetary demands. A sufficiently motivated bloc in Congress could require changes in various social policies, or national security policies, or any other politically contentious area of the law, before agreeing to increase the debt ceiling. Such tactics could force the government to choose between violating its own commitments and making changes in policies that are unrelated to those existing commitments.

With the emergence of this apparently real threat-that Congress might one day soon refuse to back up its budgetary commitments with sufficient borrowing authority-it is now possible to imagine a situation in which Congress and the president will reach a fatal impasse, failing to agree to increase the debt ceiling when obligations come due. This would, for the first time, put the United States government in the position of being politically and legally unable to pay what it has promised to pay-even when there is no economic barrier to doing so.

\section{The Applicability or Irrelevance of Section 4 of the Fourteenth Amendment}

If we reach such an impasse, it will become impossible for the president to honor his responsibilities under the Constitution to faithfully execute the laws of the United States. One way to view the problem, should such a crisis arise, is to say that the existence of the debt ceiling law itself creates the impasse, where none need exist. Without the debt

61. See Jonathan Weisman, Republicans Pledge New Standoff on Debt Limit, N.Y. Times, May 16, 2012, at A1 (reporting House Speaker John A. Boehner's vow "to hold up another increase in the federal debt ceiling unless it was offset by larger spending cuts").

62. See Budget Control Act of 2011, Pub. L. No. 112-25, § 302(a), 125 Stat. 240, 25657 (covering deficit reduction); Alan Silverleib \& Tom Cohen, White House, Congressional Leaders Reach Debt Deal, CNN (July 31, 2011), http://articles.cnn.com/ 2011-07-31/politics/debt.talks_1_debt-ceiling-debt-deal-deficit-reduction (on file with the Columbia Law Review) (summarizing terms of debt ceiling deal). 
ceiling, after all, the president could simply collect the revenues implied by the tax law, expend the funds implied by the appropriations laws, and borrow any necessary additional funds as authorized by Congress. ${ }^{63}$

In this vein, some commentary emerged during the summer of 2011, suggesting not only that the debt ceiling statute is an unnecessary (and needlessly dangerous) law, but that its existence might violate the Constitution. ${ }^{64}$ Section 4 of the Fourteenth Amendment states, in pertinent part, " $[\mathrm{t}]$ he validity of the public debt of the United States, authorized by law... shall not be questioned." ${ }^{55}$ Under one plausible reading of that provision, the debt ceiling statute-because it raises the possibility that the United States will fail to meet some of its legal obligations to pay money, as promised under the law-will bring the validity of the debt of the United States into question. If that is true, then the constitutional provision invalidates the statutory enactment, and the debt ceiling statute must be deemed invalid. The president would then ignore the debt ceiling and order the Treasury Department to issue debt otherwise authorized by Congress. This reading of the Constitution, as noted in the Introduction above, has become known as "the nuclear option." 66

Although this interpretation is not the only plausible reading of Section 4, and although (as we discuss below) it is ultimately only one way to conclude that the debt ceiling must be set aside, there is much to be said for it. The difficulty is in defining the word "questioned" in a limited and meaningful way. The only guidance on this question from the Supreme Court was issued during the Great Depression, in Perry v. United States. ${ }^{67}$ Perry was a challenge to a federal law that purported to supersede federal bond provisions entitling the bondholders to be paid principal and interest in gold. ${ }^{6}$ Although the Court found that Perry was not entitled to the particular relief he sought, en route to that holding, Chief Justice Hughes declared that Congress was constitutionally forbidden

63. See supra notes 36-37 and accompanying text.

64. See, e.g., 157 Cong. Rec. H5295-96 (daily ed. July 21, 2011) (statement of Rep. Sheila Jackson Lee) (questioning constitutionality of debt limit); Jonathan H. Adler, Is the Debt Limit Constitutional-Part Deux, Volokh Conspiracy (July 3, 2011, 1:09 PM), http://volokh.com/2011/07/03/is-the-debt-limit-constitutional-part-deux/ (on file with the Columbia Law Review) (summarizing academic debate around constitutionality of debt ceiling); Jack Balkin, The Legislative History of Section Four of the Fourteenth Amendment, Balkinization (June 30, 2011, 1:59 PM), http://balkin.blogspot.com/2011/ 06/legislative-history-of-section-four-of.html [hereinafter Balkin, Section Four] (on file with the Columbia Law Review); Garrett Epps, The Speech Obama Could Give: "The Constitution Forbids Default," Atlantic (Apr. 28, 2011, 3:56 PM), http://www.theatlantic .com/politics/archive/2011/04/the-speech-obama-could-give-the-constitution-forbidsdefault/237977/ (on file with the Columbia Law Review) (suggesting federal default would be unconstitutional).

65. U.S. Const. amend. XIV, $\S 4$.

66. See supra notes 5-7 and accompanying text.

67. 294 U.S. 330 (1935).

68. Id. at $346-47$. 
from retroactively altering the terms of its debt instruments.$^{69}$ The Chief Justice placed some reliance on Section 4 of the Fourteenth Amendment. He wrote,

We regard [Section 4] as confirmatory of a fundamental principle, which applies as well to the government bonds in question, and to others duly authorized by the Congress, as to those issued before the Amendment was adopted. Nor can we perceive any reason for not considering the expression "the validity of the public debt" as embracing whatever concerns the integrity of the public obligations. ${ }^{70}$

This language from Perry offers a broad reading of Section 4 that suggests that the validity of the debt of the United States is brought into question whenever the government acts, or threatens to act, in a way that suggests that it will not honor all of its obligations. This statement recognizes the possibility (indeed, the likelihood) that holders of federal debt- that is, the people who have loaned money to the United Stateswill have reason to seriously question whether the United States will repay the money that it borrowed if they see that the federal government has failed to live up to its other obligations. Even if the government is currently paying all interest and principal on existing government debts, current and potential lenders will have reason to question the validity of the debt if, for example, they observe the federal government refusing to pay promised Social Security benefits or refusing to reimburse a vendor for services rendered to the Defense Department.

Under this view, then, the debt ceiling is constitutionally infirm, at least as applied during a politically manufactured standoff, because its existence causes the public reasonably to question whether the federal government will soon choose not to honor its debt commitments. A court that strikes down the debt ceiling statute or a president who ignores it, under this reading, can guarantee that the commitments made by the government in its duly enacted annual budget will be met.

Although we have considerable sympathy for the "nuclear option," we recognize that the reading of Section 4 that underlies it is debatable. The quoted language from Perry, though appearing in the controlling opinion of the case, was not endorsed by a majority of the Justices of the Court. ${ }^{71}$ It is, therefore, arguably dicta. While we are persuaded that the quoted language is correct on the merits-that is, that it is dangerously shortsighted not to suspect that any defaulted obligation will bring into

69. Id. at $351-52$.

70. Id. at 354 .

71. The case was decided by a 5-4 vote. Although Justice Stone nominally concurred, rather than concurring only in the judgment, he wrote separately to indicate that he did not endorse the portion of the majority opinion in which the discussion of Section 4 of the Fourteenth Amendment appeared. See id. at 359 (Stone, J., concurring). 
question the validity of the public debt-the Supreme Court has not definitively endorsed that view in a legally binding fashion.

In addition, it is plausible to argue that Section 4 should be interpreted narrowly, especially in light of the circumstances surrounding its enactment in the aftermath of the Civil War. ${ }^{72}$ Read in that context, Section 4 chiefly targets the worry that, once fully readmitted to the Union, senators and representatives from Southern states (not to mention President Andrew Johnson) would deliberately refuse to repay debts incurred in suppressing the Confederate rebellion. ${ }^{73}$ One might concede that Section 4's literal language does not limit the provision's application to Civil War debts but nonetheless take a narrow view of what constitutes "questioning" or "public debt" by, for example, treating government failure to pay vendors for services rendered or entitlement beneficiaries their statutory benefits as outside the scope of the Amendment. ${ }^{74}$ Under an extremely narrow view, even worried bondholders would not be said to "question" the validity of the debt within the meaning of the Fourteenth Amendment unless they were told directly that the govern-

72. See Abramowicz, Beyond Balanced Budgets, supra note 20, at 581 n.94 (noting narrowest possible construction of Section 4 would limit it to Civil War debt only).

73. See id. at 582-87 (considering but rejecting this narrow interpretation of Section 4); Balkin, Section Four, supra note 64 ("[T] he goal [of Section 4] was to remove threats of default of federal debt from partisan struggle.").

74. See Abramowicz, Beyond Balanced Budgets, supra note 20, at 582-87 (suggesting general applicability of Section 4 to non-Civil War debts). Careful readers of this Article and our prior, popular writings on the debt ceiling crisis will note that our position on the meaning of Section 4 of the Fourteenth Amendment has evolved somewhat. We attribute that evolution in significant part to our enlightening exchange with Professor Tribe. Nonetheless, we continue to think that there is more to the broad reading advanced in Perry than Professor Tribe's writings suggest. For example, Professor Tribe wrote that Flemming v. Nestor, 363 U.S. 603 (1960), supports the conclusion that Section 4 does not protect Social Security recipients against having their benefits reduced. Laurence $H$. Tribe, Guest Post on the Debt Ceiling by Laurence Tribe, Dorf on L. (July 16, 2011, 5:33 PM), http://www.dorfonlaw.org/2011/07/guest-post-on-debt-ceiling-by-laurence.html [hereinafter Tribe, Debt Ceiling] (on file with the Columbia Law Review). That is a fair point, but a limited one, for at least three reasons. First, Flemming itself distinguished between mere benefits and contractual obligations, 363 U.S. at 610, and could therefore be read to provide support for more than the minimal meaning of Section 4 as applicable only to bonds. Second, the contract/benefit distinction drawn in the 5-4 ruling in Flemming may have been at least partly undermined by the later ruling in Mathews $v$. Eldridge, which treated Social Security benefits as protected property interests for procedural due process purposes. 424 U.S. 319, 332 (1976). Although procedural due process does not invariably protect against legislative abolition of the underlying property interest, the erosion of the contract/benefit distinction in the procedural context could have implications for its continued vitality in other contexts. Hence, even in a case like Flemming, Social Security benefits might now fall on the protected side of the line. Third, taken on its terms, Flemming did not decide any issue under Section 4 of the Fourteenth Amendment, of which Perry remains the case that comes closest to providing an authoritative construction. Although Professor Tribe avers that the Constitution does not use "debt" synonymously with "obligations," the Perry Court did. See supra text accompanying note 70. 
ment had decided not to pay the principal and interest promised under the terms of its debt instruments (which are legally binding contracts). ${ }^{75}$

Yet still narrower readings are available. Consider the question of whether the "debt" owed to bondholders means the principal alone, or the principal plus the interest. The interest payments, after all, only become part of the national debt when they are paid, and only if they are paid by borrowing money from other lenders. In that way, interest payments on the debt are no different from veterans' benefits, or the salaries of FBI agents. ${ }^{76}$ None are currently owed by the federal government, yet all are promised to be paid in the future under contracts entered into by the federal government.

Even the deceptively simple move of stretching the definition of "questioned" sufficiently to sweep interest payments into Section 4 is, therefore, a nontrivial interpretive exercise. We must either allow the Perry language to have some force, or we absurdly reduce the meaning of Section 4 to the point where even holders of government debt can be the victims of contractual breach without ever questioning the validity of the debt. This reductio suggests that the Perry language-which gives Section 4 something like its natural everyday meaning-is most plausible, and that the narrower readings are inappropriately cramped.

Nevertheless, there remains the opposite danger of reading the constitutional provision too broadly. Even if the word "questioned" should not be interpreted as narrowly as described above, one can reasonably worry that the word's meaning might be inappropriately expanded to include nearly anything that might make people think twice about the federal government's creditworthiness. Surely it would go too far to find a violation of the Fourteenth Amendment in any situation in which Congress seems to be unable to act responsibly. After all, an embarrassing public spectacle on the floor of Congress might make people question whether the federal government is run by fools, and thus lead them to question whether the government will be forced to default on its debt at some future time. But it is unreasonable to say that every embarrassing moment on the congressional floor actually violates Section 4 of the Fourteenth Amendment. ${ }^{77}$

75. See Abramowicz, Train Wrecks, supra note 20, at 23 (noting under one interpretation of Section 4 validity of public debt is only questioned upon nonpayment); Stern, supra note 21 (arguing more than possible default is required before "validity of public debt" is questioned).

76. Cf. Abramowicz, Train Wrecks, supra note 20, at 43-45 (arguing that reading Public Debt Clause to protect entitlements may "begin[] to stretch the Clause's meaning").

77. It would be even more unreasonable to argue that private actors could be said to violate Section 4 by questioning the government's ability to repay its debts, even though the literal language of Section 4 uses the passive voice in a way that could be interpreted to apply to anybody who questions the validity of the public debt, such as a newspaper columnist who writes that the government might default. Our conclusion on this point is 
Even under a less expansive reading of Section 4, however, there are still arguments that are simply wrong. For example, economic libertarians might argue that the issuance of debt itself could be seen to violate Section 4 , because to issue debt is to raise the possibility that it will not be repaid. The practical import of that argument is that any increases in public debt (that is, new borrowing to cover new deficits) bring into question the validity of the public debt by making it possible that the government will not be able to repay the debt. ${ }^{78}$ This argument suggests that, even in the absence of the debt ceiling, it is possible for the federal government to issue so much debt that it will someday be forced to default. ${ }^{79}$

This reasoning is flawed, for a very simple reason. All current United States debt is denominated in dollars, which the federal government alone is empowered to create..$^{80}$ Therefore, when the federal government issues new debt, lenders know that they will be repaid with dollars, and that the entity to which they loaned money can create those dollars as its own means of repayment. ${ }^{81}$ That is why, until the summer of 2011, financial markets treated United States debt securities as the equivalent of cash. ${ }^{82}$ When a security denominated in dollars is backed by the full faith and credit of the United States, there should be no risk of default. ${ }^{83}$

not driven strictly by the constitutional text, however. After all, the only other provision of the Constitution that uses the locution "shall not be questioned" is the Speech or Debate Clause of Article I, Section 6, and that provision has been held to shield senators and representatives against private civil actions. See Eastland v. U.S. Servicemen's Fund, 421 U.S. 491, 502-03 (1975) (“[T]he Clause provides protection against civil as well as criminal actions, and against actions brought by private individuals ...."). By extension, the same locution in Section 4 of the Fourteenth Amendment could also be read to protect the validity of the public debt even against private questioning. Nonetheless, such a reading, which would work a partial sub silentio repeal of the First Amendment, strikes us as beyond the realm of plausibility.

78. See Ron Paul, Default Now, or Suffer a More Expensive Crisis Later, Bloomberg (July 22, 2011, 1:00 PM), http://www.bloomberg.com/news/2011-07-22/default-now-orsuffer-a-more-expensive-crisis-later-ron-paul.html (on file with the Columbia Law Review) (arguing government has already exceeded its capability ever to repay its debt).

79. See id. ("Unless major changes are made today, the U.S. will default on its debt sooner or later ....").

80. See 31 U.S.C. $\$ 5118$ (c)(3) (2006). The Gold Reserve Act of 1934 forbade issuance of U.S. government obligations repayable in gold, although foreign central banks were still able to exchange dollars held for gold. Pub. L. No. 73-87, 48 Stat. 337. The Nixon Administration ended the latter practice in 1971. See David M. Andrews, International Monetary Power 25 (2006). By contrast, the bonds at issue in Perry were payable in gold. 294 U.S. 330, 347 (1935).

81. 31 U.S.C. $\$ 5114$ (authorizing Treasury to print money). Additional power to expand the money supply rests with the Federal Reserve System. See Fed. Reserve Sys., Purposes \& Functions 16-18 (9th ed. 2005) [hereinafter Fed. Reserve Sys., Purposes], available at http://www.federalreserve.gov/pf/pdf/pf_complete.pdf (on file with the Columbia Law Review) (describing powers Federal Reserve uses to affect monetary supply).

82. See Francis A. Longstaff, The Flight-to-Liquidity Premium in U.S. Treasury Bond Prices, 77 J. Bus. 511, 512 (2004) (noting high liquidity of U.S. Treasury bonds).

83. Id. at 525. 
There are, of course, policy and prudential reasons why a government might not wish to embark on a path that will require the creation of too much money, which is why all debt securities (public and private) face inflation risk. ${ }^{84}$ Until now, however, only federal debt securities have carried no default risk. ${ }^{85}$ Here, the key term from Section 4 is not "questioned" but rather "validity." As a technical economic matter, the validity of the debt securities of the United States is beyond question, unless Congress arbitrarily prevents the Treasury from doing what is necessary to honor those debts by imposing a binding debt ceiling.

In short, despite a legitimate range of reasonable disagreement over the meaning of Section 4, we think it is best read as obligating the federal government to pay all of its obligations but not limiting federal borrowing. Thus, during an impasse of the sort that was narrowly avoided in August 2011, Section 4 would require the president to refuse to honor the debt ceiling if doing so would cause the government to fail to meet any of its financial obligations in a timely manner. But, as we now explain, a presidential decision to avoid violating Section 4 of the Fourteenth Amendment would not necessarily ensure that the president avoided violating other constitutional obligations.

\section{Is the Debt Ceiling Really the Source of the Problem?}

Notwithstanding the controversy over the meaning of Section 4 of the Fourteenth Amendment, there is an independent argument-one that does not rely upon the Fourteenth Amendment at all-that leads to the conclusion that a president must violate the debt ceiling in order to carry out the terms of the annual budget.

In his popular writings about the debt ceiling crisis during the summer of 2011, Professor Tribe pointed out that the debate might have been inappropriately focused on the debt ceiling law in isolation, rather than viewed in the broader context in which the debt ceiling might become binding. ${ }^{86}$ If we conceive of the annual budget process as creating two laws-a tax law and a spending law-then it is not the debt ceiling alone that causes any Fourteenth Amendment problem, but rather the arithmetic implications of the three laws in combination ${ }^{87}$ : the difference

84. See Suresh Sundaresan, Fixed Income Markets and Their Derivatives 19-20 (3d ed. 2009) (noting "[m] ost debt securities carry the risk of inflation," even those indexed to inflation).

85. See Timothy W. Koch \& S. Scott MacDonald, Bank Management 493 (7th ed. 2010) (noting even full faith and credit municipal bonds and securities backed by Treasuries are still assigned default risk).

86. See Tribe, Debt Ceiling, supra note 74 (highlighting narrow view embraced by most parties to debt ceiling debate).

87. For simplicity, we refer in the text to three laws, but we have in mind three kinds of laws, because the levels of spending and taxation are themselves set by the interaction of 
between tax collections and expenditures, relative to any remaining room for borrowing under the debt ceiling. ${ }^{88}$

Under this view, even if one accepts our Perry-based argument above regarding the meaning of "questioning" the validity of the debt, it is wrong to blame the debt ceiling specifically for any problems that arise during a budget stalemate. We could, for example, say that the tax law violates the Constitution, because it fails to collect sufficient revenues to make an increase in the debt ceiling unnecessary. Similarly, the spending law brings the validity of the debt into question, by obligating the government to spend more money than it can raise from authorized taxation and authorized borrowing.

There is, as we discuss further in Part II below, much to this argument. Even so, it is worth considering the unique nature of the debt ceiling law, to determine whether there is anything to the idea that there is a unique problem with the debt ceiling that would make it-and it aloneconstitutionally problematic.

As noted earlier, the debt ceiling is a relatively recent invention. ${ }^{89}$ The nation existed for well over a century without a debt ceiling, passing annual budgets that combined taxes and spending in various amounts. Although the federal government and its debt were both relatively small during that time period, the federal debt did exist, and it did fluctuate over time in response to differences in taxing and spending.

The debt ceiling, therefore, is an appendage that was added to the system long after the federal government began operating successfully. To be sure, fiscal conservatives may view the debt ceiling as a very useful appendage. Each time the debt approaches the debt ceiling, citizens and politicians who believe that government is too large can use that fact to impose what they view as fiscal discipline in two ways: First, as in the 2011 impasse, they can demand concessions from their political adversaries as the price of agreeing to raise the debt ceiling; and second, they can make their case to the public that the need to raise the debt ceiling reflects government profligacy. Nevermind that the charge need not be true. Even if the ratio of debt to GDP shrinks, and even if the government only runs deficits that are sustainable over the long term, economic growth will mean that Congress repeatedly runs up against the limit of the dollar-denominated debt ceiling. The important point is that the debt ceiling is a visible and useful tool for imposing fiscal austerity-whether needed or not. And so, for those who believe that fiscal austerity is needed, the debt ceiling may serve an important function.

the annual budget law, preexisting statutes governing mandatory spending, and all of the complexities of the Internal Revenue Code.

88. See Tribe, Debt Ceiling, supra note 74 (discussing relation of these three laws and how, in combination, they create constitutional problem).

89. See supra notes 50-52 and accompanying text. 
But even granting that, the debt ceiling is hardly essential for imposing fiscal austerity. As noted above, fiscal austerity, or any other plausible policy goal that the debt ceiling might help to accomplish, can be achieved in the absence of the debt ceiling. ${ }^{90}$ If Congress and the president think that the debt is too high, then they can combine tax increases and spending reductions to address that concern.

By contrast, the federal government could not function without spending laws and tax laws. Those laws must be specific enough to allow the executive branch to know how to spend money, and from whom to collect how much in revenues. Allowing the debt ceiling to override one or both of the tax and spending laws would therefore create a legal vacuum, leaving the executive branch without guidance from the legislative branch about how to change taxes or spending while maintaining a level of debt below the ceiling. ${ }^{91}$

We do not, however, view this argument as essential to our ultimate conclusion. While there are strong reasons to view the debt ceiling as a "lesser" law than the tax and spending laws, it is sufficient for our purposes to accept Professor Tribe's point that there is an interaction problem among the laws. ${ }^{92}$ And as we explain in the next Part, the problem is not simply that the laws conflict, but that they conflict in a way that gives the president no constitutional options. Once one recognizes that a president cannot simultaneously carry out all three laws without violating the Constitution, it is necessary to determine how a president should decide which law to set aside. With nothing but unconstitutional choices, what should a president do?

\section{The PREsident's Trilemma: Which Duty Must He IGNORE When He FACES THREE UNCONSTITUTIONAL CHOICES?}

The interaction of the spending law, the tax law, and the debt ceiling law potentially creates an unsolvable problem. For example, if Congress were to authorize spending that exceeds tax collections by one trillion dollars in a year, at a time when the existing federal debt is only one-half trillion dollars below its statutory ceiling, then the president could not execute all three laws as written. Faced with that impossible choice, the president risks acting unconstitutionally no matter what he might do, because he will have failed to execute at least one duly enacted

90. See supra text accompanying notes $43-46$.

91. Congress could specify, in advance, how taxes should be increased or spending reduced, in the event that the debt ceiling kicks in, through "fallback" provisions in the relevant statutes. See Michael C. Dorf, Fallback Law, 107 Colum. L. Rev. 303, 304-10 (2007) (discussing policy and constitutional implications of fallback provisions). But Congress has not done so.

92. See supra notes $86-88$ and accompanying text. 
law of the United States. ${ }^{93}$ He thus faces a "trilemma": a choice between three bad options, all of which are unconstitutional. ${ }^{94}$ While it is also possible for the president to combine unilateral actions on taxes, spending, and debt-thus potentially violating three separate provisions of the Constitution simultaneously-we find it more useful to discuss the three separately. This Part offers constitutional and prudential grounds in support of the conclusion that, faced with the trilemma, the president should set aside the debt ceiling law. Then Part III draws broader lessons about the criteria the president and other actors should use for choosing among unconstitutional options.

\section{A. Three Powers Reserved to Congress}

Article I of the Constitution grants to Congress, rather than to the president, all three powers at play in this debate: taxing, spending, and borrowing. ${ }^{95}$ Under Section 8, Congress has "Power To lay and collect Taxes," to "borrow Money on the credit of the United States," and to "provide for the... general Welfare" through the expenditure of money. ${ }^{96}$

While there are timeless controversies over the extent of Congress's powers under Article I, ${ }^{97}$ the point here is that any such powers are in Congress's hands, not the president's, at least absent a valid delegation

93. See U.S. Const. art. II, $\S 3$ (stating president shall "take Care that the Laws be faithfully executed"). As Representative John Vining put it,

What are [the president's] duties? To see the laws faithfully executed; if he does not do this effectually, he is responsible. To whom? To the people. Have they the means of calling him to account, and punishing him for neglect? They have secured it in the Constitution, by impeachment, to be presented by their immediate representatives ....

Julie R. O'Sullivan, The Interaction Between Impeachment and the Independent Counsel Statute, 86 Geo. L.J. 2193, 2203 (1998) (quoting 1 Annals of Cong. 594 (1789) (Joseph Gales ed., 1834) (statement of Rep. John Vining)).

94. As noted in the Introduction, we are aware that there are some plausibly constitutional methods by which the president could raise money to finance the difference between spending and taxes. See supra notes 20-22. Selling national parks, selling options to the Federal Reserve, and similar ideas are innovative and clever, but they strike us as perfect examples of the type of action most directly implicating at least the spirit of Section 4 of the Fourteenth Amendment. That is, if the president were seen selling Alaska back to the Russians, or minting large platinum coins, or anything along those lines, then any reasonable person would question the validity of the debt of the United States. No functioning government could engage in such Hail Mary desperation plays without undermining public confidence in all of its finances, perhaps fatally. As we explain below, even if such tactics were deemed constitutionally valid, the government should not have to try them if they would bring about financial ruin. See infra Part III.C.

95. U.S. Const. art. I.

96. Id. art. I, § 8 .

97. See Gerard N. Magliocca, A New Approach to Congressional Power: Revisiting the Legal Tender Cases, 95 Geo. L.J. 119, 120 (2006) (noting question of "the scope of Congress's enumerated powers is ... constitutional law's oldest debate”). 
by Congress to the president. For a president to choose unilaterally to collect taxes in a way not authorized by Congress, or to spend money in a way not authorized by Congress, or to borrow money in amounts not authorized by Congress, violates the separation of powers enshrined in the Constitution. ${ }^{98}$

If Congress, either by choice or by default, puts the president in the position of having to violate his oath of office, how should the president proceed? The most aggressive approach would be for the president simply to assume all powers otherwise reserved to Congress, on the theory that he cannot be expected to obey the contradictory dictates of a dysfunctional body.

But this framing of the question may be misleading. Congress does not act alone, and so the president may share responsibility for its dysfunction. Did the president sign the budget bill that put Congress on a collision course with the debt ceiling? Did he threaten to veto a bill raising the debt ceiling if it contained (or did not contain) some other provision he disapproved (or insisted upon)? The trilemma occurs as a result of a systemic failure rather than simply congressional dysfunction.

Moreover, as we elaborate at greater length in Part III, even if the president bears no substantial responsibility for the trilemma, he should follow the path that would do the least violence to the constitutional prerogatives of Congress. In other words, the president should engage in the most minimal course of action possible and do everything practicable to allow Congress later to undo what he has done, if Congress ultimately determines that the president's extraordinary (but necessary) exercise of power was unwise.

This analysis suggests that Congress itself could provide guidance regarding its priorities among the three possible courses of action, explaining or revealing which of the three powers it cares about the least. Naturally, any such analysis is comparative, because Congress should rightly be concerned about guarding all of its enumerated powers. Moreover, these three powers are all highly valued and closely guarded legislative prerogatives. The question is not which choice is best, but which is least bad.

Among the three possibilities, the taxing power would seem to be the most important power reserved to Congress. ${ }^{99}$ From the founding, the notion of limited government was, in significant part, a commitment

98. "When the President acts in absence of either a congressional grant or denial of authority, he can only rely upon his own independent powers," which do not include those powers expressly granted by Article I, Section 8, to Congress. Youngstown Sheet \& Tube Co. v. Sawyer, 343 U.S. 579, 637 (1952) (Jackson, J., concurring).

99. See, e.g., Tucker v. Ferguson, 89 U.S. (22 Wall.) 527, 575 (1874) ("The taxing power is vital to the functions of government. It helps to sustain the social compact and to give it efficacy. It is intended to promote the general welfare. It reaches the interests of every member of the community."). 
to a limitation on the power to tax. ${ }^{100}$ "No taxation without representation" is only the most memorable of the expressions of this idea, reserving to the people's representatives the power to collect taxes. ${ }^{101}$ That power is also the first of Congress's powers listed in Section 8 of Article I. ${ }^{102}$ Certainly, we are unaware of any situation in which a president has attempted to collect taxes without authorization by Congress; and it is difficult indeed to imagine any Congress acceding to such a usurpation of its powers.

Regarding the spending power, the picture is a bit more nuanced. In the early years of the Republic, Congress passed laws that authorized the president to spend "up to" certain sums of money, and the president was accordingly able to carry out his constitutional duties while spending money in amounts not precisely specified by Congress. ${ }^{103}$

In most areas of the federal budget, however, that practice has long since ended. Congress now typically specifies precise amounts of money (or, in the case of so-called entitlement programs, precise formulae to determine amounts of money) that the president must spend for each authorized program. ${ }^{104}$ When Congress appropriates the money necessary to fund those authorized programs, it effectively orders the president to spend no more and no less than those amounts. It would be odd, indeed, if a president were to assert that he could choose to, say, send Medicare beneficiaries (or their medical care providers) less money than they would be entitled to receive under the relevant statute.

Moreover, we need not speculate about what would happen if a president were to assert such authority. The impoundment controversy during the Nixon Administration involved a direct confrontation be-

100. See Charles Lockhart, American and Swedish Tax Regimes-Cultural and Structural Roots, 35 Comp. Pol. 379, 385, 391-92 (2003) (explaining United States' tax revenues remain low in relation to other industrial countries because of historical "fidelity to a neo-Lockean conception of limited government" which stems from time of American Revolution).

101. See, e.g., Grant Dorfman, The Founders' Legal Case: "No Taxation Without Representation” Versus Taxation No Tyranny, 44 Hous. L. Rev. 1377, 1378 (2008) (noting phrase has become “'mother's milk' of American history education”).

102. U.S. Const. art. I., $§ 8$.

103. See Roy E. Brownell II, The Constitutional Status of the President's Impoundment of National Security Funds, 12 Seton Hall Const. L.J. 1, 22-30 (2001) (discussing early laws under which "President Washington was given broad discretion over appropriations through use of 'lump-sum' appropriations” to expend funds or leave funds unexpended as he saw fit).

104. Cf. W. Cent. Mo. Rural Dev. Corp. v. Donovan, 659 F.2d 199, 202 (D.C. Cir. 1981) (rejecting challenge to presidential deferral of spending of allocated funds on ground that it was merely temporary, and thus not in contravention of statutory requirement that funds be spent). For further discussion of direct-spending legislation and entitlement programs, see Schick, supra note 31, at 57-81 (discussing tactics to reduce discretionary spending and Clinton's efforts to thwart cuts in entitlement programs in 1995-1996 budget). 
tween the executive and legislative branches, with Congress objecting to Nixon's theory of an "imperial presidency," in which the president would have the power to selectively reduce certain spending programs at his discretion. ${ }^{105}$

The result was the Impoundment Control Act of 1974, under which the president may only propose "rescissions" of appropriated spending. ${ }^{106}$ Congress, however, need not act on such proposals, and the president's power to withhold funds ends after forty-five days. ${ }^{107}$ Congress, therefore, has made a strong statement of principle, affirming its power under the Constitution to set the exact sums of money to be spent on each program, not merely the upper limits.

Arguably, moreover, the Impoundment Control Act was unnecessary to affirm Congress's powers. While other provisions of that law have surely helped to create mechanisms for resolving disputes among the branches, even before Congress acted lower courts invoked the Constitution in uniformly ruling against President Nixon's attempts to impound funds. ${ }^{108}$ Passage of the Act mooted those cases before they reached the Supreme Court, but the fundamental idea that the power to spend implies the power to spend in exact amounts is persuasive and, in our view, also strongly implied by the Supreme Court's invalidation of the Line Item Veto Act in Clinton v. City of New York. ${ }^{109}$

For the immediate purpose of determining Congress's priorities, however, it is the passage of the Impoundment Control Act itself that provides useful guidance for future controversies. Congress has demon-

105. See Arthur M. Schlesinger, Jr., The Imperial Presidency 235-40 (Mariner Books 2004) (1973) (describing President Nixon's use of impoundment as instrument of policy); Thomas E. Cronin, A Resurgent Congress and the Imperial Presidency, 95 Pol. Sci. Q. 209, 215-16 (1980) (discussing Nixon's impounding funds to withhold spending from certain programs and Congress's adverse reaction to his "extensive policymaking").

106. Congressional Budget and Impoundment Control Act of 1974, 2 U.S.C. $\S \S 681-$ 688 (2006). See also Cronin, supra note 105, at 221 (noting Congress passed Act partly as means of reasserting its authority over budget).

107. 2 U.S.C. $\$ 683$; see Schlesinger, supra note 105, at 477 (describing Congress's discretionary power to act on presidential rescission proposals).

108. See Schlesinger, supra note 105, at 397 (discussing history of courts ruling unanimously against impoundment); see also Pennsylvania v. Lynn, 362 F. Supp. 1363, 1372 (D.D.C. 1973) ("It is not within the discretion of the Executive to refuse to execute laws passed by Congress but with which the Executive presently disagrees."), rev'd, $501 \mathrm{~F}$. 2d 848 (D.C. Cir. 1974); Campaign Clean Water, Inc. v. Ruckelshaus, 361 F. Supp. 689, 700 (E.D. Va. 1973) (holding that impoundment of fifty-five percent of funds allocated to administration of Water Pollution Control Act was "flagrant abuse of executive discretion" and therefore void).

109. 524 U.S. 417, 449 (1998). Even Justice Scalia, who dissented in Clinton, acknowledged that President Nixon was mistaken in his assertion of a constitutional power to impound appropriated funds in the teeth of a congressional command to spend those funds. Id. at 468 (Scalia, J., dissenting) (citing Train v. City of New York, 420 U.S. 35 (1975)). 
strated-both by passing the Act and by refusing to grant subsequent presidential rescission requests-that it wishes to guard its power to spend against presidential encroachment.

Finally, what about Congress's power to authorize the borrowing of money? The existence of the debt ceiling law, of course, suggests that Congress wishes to limit the amount of money that the government can borrow. ${ }^{110}$ In practice, however, Congress has generally treated the debt ceiling as a symbolic measure or, at most, a bargaining chip of relatively little value; prior to 2011, everyone understood that the debt ceiling would ultimately be raised. Each time an increase in the debt ceiling has been resisted, it has been generally understood that the dollar limit of the debt ceiling was being used opportunistically. ${ }^{111}$ Even President Obama, when he served in the Senate, once voted against a debt ceiling increase, with no indication that he was doing so because of concerns about the specific limit involved. ${ }^{112}$ Taking a stand on the national debt was politically useful, but no one doubted that Congress would ultimately raise the debt ceiling.

Yet this line of reasoning might suggest the importance of the debt ceiling in case of a real impasse. That is, if Congress ever actually were to refuse to raise the debt ceiling, then that would be an unmistakable (albeit surprising) statement that it cares deeply about the level of debt. As we argue below, however, it is difficult to reconcile that inference with Congress's having passed tax and spending laws that would otherwise require an increase in the debt.

In any event, we need not stake our argument on the proposition that Congress does not care about the debt ceiling. Congress's refusal to change any of the three laws-which is the situation that gives rise to this entire analysis-gives us no reason to think that it cares more about its power to limit borrowing than about its other powers. At most, through a failure to raise the debt ceiling, Congress could be read to be saying that it no longer cares less about protecting its borrowing powers.

It is not surprising that reading Congress's collective mind regarding these foundational principles is difficult. Each specific power granted to Congress under the Constitution is important on its own merits. As a comparative matter, however, it is difficult not to view the debt ceiling as

110. See 31 U.S.C. $§ 3101$ (2006) (establishing public debt limit).

111. See Anita S. Krishnakumar, In Defense of the Debt Limit Statute, 42 Harv. J. on Legis. 135, 156 (2005) (stating Congress has used "votes on debt limit increase legislation .... as a vehicle for passage of budget-reform or other unrelated legislation"). The debt ceiling law has been treated "as a dangerous 'weapon' used by Congress to force the President to make uncomfortable compromises on issues unrelated to the debt." Id. at 138 , n.18.

112. See 152 Cong. Rec. 3845 (2006) (listing then-Senator Obama as voting "Nay" on H.R.J. Res. 47, 109th Cong. (2006)). 
the least important manifestation of Congress's efforts to protect its prerogatives.

\section{B. Rules of Interpretation, As Applied to the Debt Ceiling Controversy}

When legal provisions are in conflict, or in cases of ambiguity, various interpretive doctrines may be available to resolve the issues at stake. One such tool is the principle of constitutional avoidance. Perhaps the various acts of Congress can be collectively construed to avoid the conclusion that the President was obligated to execute some unconstitutional law. Perhaps the budget that Congress enacted in the spring of 2011 impliedly repealed the debt ceiling limit. If so, then the President would not have faced a trilemma at all. Ignoring the debt ceiling would have been the right choice because the debt ceiling would no longer exist.

Yet, as a judicial doctrine, constitutional avoidance only operates to permit the selection of a "plausible" construction of a statute. ${ }^{113}$ We see no reason why constitutional avoidance should be applied any more broadly by the executive branch. ${ }^{114}$ The reason why courts will not unduly strain statutory text to avoid a constitutional question is to preserve Congress's primacy in legislation. That primacy is threatened by executive bending of the law no less than by judicial bending. Accordingly, we think the president must ask the same question that a court would ask to determine whether constitutional avoidance enables the conclusion that the budget law impliedly repealed the debt ceiling: is that a plausible reading of the budget law?

Although we favor repeal of the debt ceiling on policy grounds, we do not think that Congress's adoption of a budget in 2011 can plausibly be read as having impliedly repealed the debt ceiling. If the enactment of a budget in which spending will eventually exceed revenues by an amount greater than the room remaining under the debt ceiling acts as a tacit repeal of the debt ceiling, then the debt ceiling will have been read to do literally nothing. After all, the debt ceiling only constrains government borrowing in just such circumstances. Accordingly, reading the budget law to repeal the debt ceiling law would avoid a constitutional question only by violating the canon of statutory construction that

113. Milavetz, Gallop \& Milavetz, P.A. v. United States, 130 S. Ct. 1324, 1333 (2010) (quoting Clark v. Martinez, 543 U.S. 371, 381 (2005)) (internal quotation marks omitted).

114. Professor Morrison has argued that in some circumstances constitutional avoidance should not apply at all within the executive branch. See Trevor W. Morrison, Constitutional Avoidance in the Executive Branch, 106 Colum. L. Rev. 1189, 1239-58 (2006) (pointing to institutional advantages that render statutes relatively unambiguous for executive branch actors). But we know of no argument for the executive applying the principle of constitutional avoidance more broadly than courts apply it. 
instructs courts to "disfavor interpretations of statutes that render language superfluous."

In addition, there is a longstanding canon of statutory construction disfavoring repeal by implication, absent "clear and manifest" evidence of legislative intent. ${ }^{116}$ Yet there is essentially no evidence in the budget act itself or anywhere else that Congress, in passing the budget, intended to repeal the debt ceiling. When Congress passed the budget in 2011, it did so knowing that every other time it had passed a budget that required borrowing beyond the debt ceiling, further legislation was subsequently enacted raising the debt ceiling. Against that background, it is not plausible to conclude that Congress thought—but did not say in the legislation or anywhere else-that this time things were different.

If canons of construction cannot dissolve the trilemma, they may nonetheless provide the president with guidance about Congress's priorities-and thus enable him to choose an unconstitutional course that minimizes the frustration of those priorities. As we now explain, the two most useful doctrines both point in the same direction, suggesting that the debt ceiling should give way when it is in conflict with the taxing and spending provisions of the government's budget.

The "last in time" rule suggests that Congress's most recent enactments provide the best guide to its priorities. ${ }^{117}$ Congress legislates in light of existing law, and thus it presumably knows when it is passing new legislation that would make it impossible for the president to meet his obligations under both the older and newly enacted laws.

In the case of the debt ceiling, Congress in spring 2011 passed a budget. ${ }^{118}$ According to all estimates available at the time, that budget implied that the government would reach its official debt limit in May; all of the executive branch's legally permissible delaying tactics (such as temporarily suspending reinvestment of certain government funds) would be exhausted by early August, before the end of the fiscal year. ${ }^{119}$

115. Conn. Nat'l Bank v. Germain, 503 U.S. 249, 253 (1992).

116. See Hui v. Castenada, 130 S. Ct. 1845, 1853 (2010) (citing Hawaii v. Office of Haw. Affairs, 556 U.S. 163, 175 (2009)).

117. See, e.g., Whitney v. Robertson, 124 U.S. 190, 194 (1888) (noting when two legal instruments conflict, "the one last in date will control the other"); Boudette v. Barnette, 923 F.2d 754, 757 (9th Cir. 1991) ("When two statutes conflict the general rule is that the statute last in time prevails as the most recent expression of the legislature's will.").

118. See Janet Hook, Congress Puts Haggling Aside to Pass 2011 Budget Bill, Wall St. J., Apr. 15, 2011, at A5 (describing months of congressional conflicts leading up to passage of 2011 budget).

119. See James Risen, Debt Ceiling Increase Is Expected, Geithner Says, N.Y. Times, Apr. 18, 2011, at A14 ("The administration says the legal debt limit, now just over $\$ 14$ trillion, will be reached [in May]. Many economists have warned that if the ceiling is not raised, the United States will soon begin to default on its debt, and that could set off an international financial crisis."); Press Release, U.S. Dep't of the Treasury, Treasury: No Change to August 2 Estimate Regarding Exhaustion of U.S. Borrowing Authority (July 1, 
Yet the budget called for levels of spending and taxes that would require increases in the debt to levels beyond the statutory limit. ${ }^{120}$ If the last-intime doctrine has any purchase here, it leads to the conclusion that, if push came to shove, Congress must not have wanted the President to enforce the debt ceiling as much as it wanted the President to tax and spend in accordance with the budget. If Congress had cared enough about the debt ceiling, it had all of the tools necessary to avoid a conflict that would lead to the President's trilemma.

Another useful interpretive doctrine states that "the specific dominates the general." ${ }^{21}$ This maxim captures the idea that general statutes adopt policy goals that have some weight, but that drafters of statutes legislate in more detail when they mean to specify a particular result. If the general statutes can be carried out without conflicting with other laws, then they must be followed. If not, however, then Congress's attention to detail should trump its more general statements.

Of course, the debt ceiling is in one sense very specific. It states a precise number beyond which the national debt may not rise. ${ }^{122}$ But the taxing and spending laws are much more specific than the debt ceiling statute in that they express congressional will on a host of specific details, rather than just one aggregate number. For the reasons discussed in Part II.D below, that specificity should strongly point the president towards setting aside the debt ceiling when he is faced with the trilemma. To put the point briefly, the legislative effort inherent in the taxing and spending laws represents such a delicate balancing act that we must presume that Congress's intent would be frustrated to a much greater degree by a president who elevates the blunt instrument of the debt ceiling above those other, highly nuanced laws, than by a president who subordinates the debt ceiling to Congress's decisions about spending and taxes.

But suppose Congress wanted the president to observe a hard debt ceiling-one that would prevail over budget and tax laws that called for

2011), available at http://www.treasury.gov/press-center/press-releases/Pages/tg1225 .aspx (on file with the Columbia Law Review); Letter from Timothy F. Geithner, Sec'y of the Treasury, to Harry Reid, Senate Majority Leader (Apr. 4, 2011) (on file with the Columbia Law Review) (describing tactics available to executive branch in order to delay default).

120. See Mindy R. Levit et al., Cong. Research Serv., R41633, Reaching the Debt Limit: Background and Potential Effects on Government Operations 12 (2011) [hereinafter 2011 CRS Report], available at http://fpc.state.gov/documents/organization /157101.pdf (on file with the Columbia Law Review) ("[T] he federal government will have to issue an additional $\$ 738$ billion in debt on net above the current statutory limit to finance all obligations for the remainder of [fiscal year 2013].”).

121. See, e.g., Thompson v. Calderon, 151 F.3d 918, 929 (9th Cir. 1998) (noting "more recent and specific statute" controls over general statute); Greene v. United States, 79 F.3d 1348, 1355 (2d Cir. 1996) ("When two statutes are in conflict, that statute which addresses the matter at issue in specific terms controls over a statute which addresses the issue in general terms, unless Congress has manifested a contrary aim.”).

122. 31 U.S.C. $\$ 3101$ (2006) (stating federal government may not at any time have outstanding debt obligations exceeding $\$ 14,294,000,000,000)$. 
spending that leaves a shortfall which would otherwise necessitate borrowing beyond the debt ceiling. Does our application of the canons of construction render such a choice impossible? Hardly.

If Congress really wanted a hard debt ceiling, it could so specify in the debt ceiling and/or its budget and tax bills. For example, the debt ceiling statute might state something like the following:

In the event that any future Act appropriates funds in amounts that cannot be paid without borrowing beyond the limits of this debt ceiling, such future Act shall be construed to authorize the president to decline to spend such sums as he, in his sound discretion, deems appropriate to impound.

That sort of debt ceiling law would work a partial repeal of the Impoundment Control Act, and if Congress were then to pass a budget that required borrowing beyond the debt ceiling, the budget would be construed in light of the debt ceiling law as prioritizing spending cuts. But in such a scenario, the president would not be cutting spending because cutting spending would be less unconstitutional than ignoring the debt ceiling; in such a scenario, cutting spending would not be unconstitutional at all (so long as the particular spending cuts did not violate Section 4 of the Fourteenth Amendment or some other constitutional provision). Put differently, Congress can insist on a hard debt ceiling, but it may have difficulty prospectively insisting on a hard debt ceiling as a favored unconstitutional option.

\section{Practical Issues Raised by Presidential Unilateralism}

Beyond Congress's own indications of its priorities, there are practical questions that arise when considering which of the three powers of Congress the president might usurp when faced with a trilemma. Examining the ease or difficulty of carrying out one or another option might offer guidance about the president's best course of action, thereby helping to answer the question of which unconstitutional option is least unconstitutional. We return to the question of why such pragmatic considerations bear on the relative measure of unconstitutionality in Part III.

1. When the President Cuts Spending. - President Obama, along with many commentators, concluded in the summer of 2011 that he would be forced to violate the Constitution by spending less than Congress had authorized and appropriated in the spending law. ${ }^{123}$ If he had followed through, how would that have happened?

Those who were worried about the validity of the public debteither for constitutional reasons or out of concern that failing to pay the nation's creditors could create a financial and economic crisis-

123. Of course, the President did not say that spending less than Congress had appropriated would violate the Constitution, but the conclusion follows from our earlier discussion of the impoundment controversy. See supra text accompanying notes 103-109. 
suggested that the president could simply set aside funds to pay those obligations that he deemed to be the most important. ${ }^{124}$ So long as the president did not use the opportunity to exact political retribution, or to impermissibly target certain groups in a way that would violate equal protection, this approach would simply entrust to the president the power to decide who should not be paid.

As it turns out, however, doing so would be surprisingly difficult under the laws and procedures that usually govern federal spending. Because tax revenues arrive at the Treasury daily, in varying amounts, the government's ability to pay its bills without borrowing will depend on which bills happen to come due on the days when the government happens to be collecting sufficient tax revenues. ${ }^{125}$ A Social Security check that could not be paid on Tuesday might be payable on Wednesday. However, even if the Tuesday payment is not made, there will be other payments that are due on Wednesday. If the amount of tax revenue coming in during Wednesday would be enough to pay Wednesday's bills, but not both Tuesday's carryovers plus Wednesday's bills, then someone will still not be paid.

Under current law, if the government has enough money in the Treasury on any given day to pay the bills that are then due, it must pay those bills. ${ }^{126}$ The debt ceiling does not override that requirement, because there would be (by assumption) sufficient non-borrowed funds to cover the day's required expenditure. If the president tried to argue that he must prioritize the older unpaid bills over the current bills, Wednesday's would-be recipients could reasonably argue that there is no principle under the law that authorizes the president to set priorities in that way. Tuesday's recipients should, under an equally plausible argu-

124. See, e.g., Tom McClintock, Debt Reduction Means Difficult Decisions; Families Get What Washington Doesn't: Live Within Your Means, Wash. Times, July 28, 2011, at B1 ("President Obama has both the legal authority and constitutional obligation to prioritize payments to prevent a default. The problem is that a lot of other bills would go unpaid...."); see also 2011 CRS Report, supra note 120, at 13 (discussing different legislation proposals made by congressmen that would prioritize payment of certain obligations, such as principal and interest on debt or Social Security benefits, over other obligations).

125. The Financial Management Service publishes a Daily Treasury Statement that reports the amount of revenue received by the Treasury, daily withdrawals, and debt transactions on a given day. See Overview, Daily Treasury Statement, Fin. Mgmt. Serv., www.fms.treas.gov/dts/overview.html (on file with the Columbia Law Review) (last updated Dec. 4, 2009).

126. See Mindy R. Levit et al., Cong. Research Serv., R41633, Reaching the Debt Limit: Background and Potential Effects on Government Operations 8 (2012) [hereinafter 2012 CRS Report], available at http://www.fas.org/sgp/crs/misc/R41633.pdf (on file with the Columbia Law Review) (stating U.S. Treasury is required "to make payments on obligations as they come due" because it "lacks formal legal authority to establish priorities to pay obligations"); see also Binyamin Appelbaum, Treasury Prioritizing Payments, N.Y. Times, July 28, 2011, at B6 (noting Social Security benefits might go unpaid if debt limit is reached because of requirement that Treasury make payments as they become due). 
ment, be out of luck until there is enough money to pay a particular day's recipients plus all unpaid carryover bills. And if such a day never comes, then there is no reason why the earlier obligations are more binding than the later ones. The short-term timing of these payment streams is, in most cases, a matter of happenstance.

The analysis could also be affected by the nature of the payments that are due. In some cases, a day's or week's delay is little more than an annoyance, while in others, justice delayed is truly justice denied. For example, a person who is owed money by the federal government could be relying on that money to fund a down payment on a house, where even a day's delay can be sufficient to unravel an entire sale-or even a series of sales, where the seller in one deal expects to use her proceeds to become the buyer in a related sale. Again, the nearly random timing of the specific payment obligations, in conjunction with the equally random timing of tax receipts, suggests that it would be difficult indeed to create a principled priority system that forces some recipients to wait while others are paid.

This problem would become even more difficult if the president were to try to hoard funds from day to day in anticipation of high-priority obligations that are expected to arise in the near future. For example, if the president knows that certain interest payments to government bondholders will be due on Friday, and he does not expect there to be enough money coming in on Friday to cover those payments, he might refuse to make payments earlier in the week, even when the concurrent flow of tax revenues would otherwise be sufficient to cover the payments due on those days. If Treasury is legally required to pay money due when it is due, so long as there is money on hand, then certainly the disappointed would-be recipients of those payments could bring actions against the government. ${ }^{127}$

But, one might ask, wouldn't the president make these decisions at the wholesale level? The president could establish a formula of the following sort: Bondholders and military personnel get paid in full; the remaining shortfall is then made up by an equal percentage reduction among all prospective federal payees based on Treasury's projection of the size of the shortfall. Such an algorithm would not require Treasury or the president to decide, at least on a day-by-day basis, whom to pay and how much to pay them.

127. In order to satisfy the Article III requirements for standing, a plaintiff must have suffered a "personal injury fairly traceable to the defendant's allegedly unlawful conduct and likely to be redressed by the requested relief." Allen v. Wright, 468 U.S. 737, 751 (1984). When "the plaintiff is himself an object of the action (or forgone action) at issue ... there is ordinarily little question that the action or inaction has caused him injury, and that a judgment preventing or requiring the action will redress it." Lujan v. Defenders of Wildlife, 504 U.S. 555, 561-62 (1992). Suits against the government for funds allegedly unlawfully withheld fall into this uncontroversial category. 
We concede that it is possible to rewrite the laws and procedures to allow any set of priorities to be met, but the process of doing so requires more changes to the law and to executive procedures than might at first be obvious. Moreover, even if the president does not engage in the kinds of impermissible favoritism that unilateral spending cuts might allow, assumption of the power to choose among decision procedures greatly expands the power of the president to make choices that cross the line into policy decisions-without any legislation that could fairly be construed as a delegation of that power to him. Setting up rules that protect would-be recipients of certain payments, such as the example in the previous paragraph, necessarily disfavors others. Congress has delegated some limited authority to the president to prioritize certain national defense spending, ${ }^{128}$ and the president has in turn delegated some of that authority to federal agencies, ${ }^{129}$ but those limited delegations merely underscore the absence of any broader delegation of prioritization authority to the president. For the president to make such choices without prior congressional authorization is for him to assume significant legislative power. ${ }^{130}$

In short, seemingly simple rules like "across-the-board cuts" or "prioritization of bondholders" turn out, on the ground, to be anything but simple. Telling the president to pick winners and losers-even if he does so in a way that seems to employ a "clean" rule, without the apparent exercise of day-to-day discretion-both confers awesome power on the president and increases the likelihood of arbitrary harm to innocent parties.

2. When the President Increases Borrowing. - If the president, instead of cutting spending, decides to ignore the debt ceiling, how would he proceed? The issuance of government debt is significantly less complicated than the determination of government spending levels, because debt is a relatively undifferentiated (and completely monetizable) asset. Whereas spending cuts can result in something as serious as missed chemotherapy treatments or as inconsequential as delays in reimbursing a person's travel expenses, borrowing money has more predictable and direct consequences. No one is forced to lend money, and the government simply borrows as much as it needs to cover its appropriated spending, and no more. ${ }^{131}$ Other than the details of the maturities of the debt instruments, the process is straightforward and unremarkable.

128. See Defense Production Act of 1950, Pub. L. No. 84-774, § 101, 64 Stat. 798, 799 (codified as amended at 50 U.S.C. app. $\$ 2071$ ) (granting president authority to allocate resources and set domestic spending priorities in matters of national defense).

129. See Exec. Order No. 13,603, 77 Fed. Reg. 16,651, 16,652-58 (Mar. 16, 2012).

130. See supra notes 104-109 and accompanying text (describing limitations Congress placed on president's ability to change budget allocation).

131. See 2012 CRS Report, supra note 126, at 1-2 (describing drivers of federal borrowing). 
From an administrative standpoint, therefore, the issuance of debt poses no difficulties. There are federal employees who regularly go through the process of issuing new federal debt, using well-established mechanisms to interact with potential lenders in the financial markets. ${ }^{132}$ If the president wishes to issue additional debt, even if that debt would bring the government's total borrowing level above the current ceiling, he can easily issue an order to do so. The recipients of that order would know exactly what to do, without having to make judgment calls, and without needing to alter any other laws or procedures that are currently in place.

Consequently, as a practical matter exceeding the debt ceiling is the essence of simplicity, especially compared to cutting spending. The more difficult practical question, however, is how the potential lenders to the United States would react to the offer of new debt securities that appear to violate the borrowing clause of Article I, Section $8 .{ }^{133}$ Would such lenders assume that the new debt is still backed by the full faith and credit of the United States, even though only the president has authorized the borrowing?

In part, the answer to this question depends upon the degree of political dysfunction that attends the crisis at hand. If it appears that the negotiations passed the witching hour by mere bad luck, but that things will soon return to normal, then it is easy to imagine that the subsequent legislative compromise will include an after-the-fact guarantee of the validity of what we will call the "Presidential bonds." If, however, it appears that the political crisis will be longer-lasting, then the risk to lenders is higher, making them likely either to refuse to lend, or to require higher interest payments (thus exacerbating the government's long-term borrowing problems).

If the government simply defaults up front, however, one would expect markets immediately to respond badly, making it more difficult and expensive to return the government to its status as a preferred borrower. ${ }^{134}$ Avoiding default by issuing potentially illegitimate debt could, on the other hand, lead to the same result. ${ }^{135}$ The irony, there-

132. The Bureau of the Public Debt is the agency within the U.S. Department of the Treasury that issues debt obligations to the public in order to finance government operations. This agency handles the sale of government securities on the primary and secondary markets. It also auctions about $\$ 4.5$ trillion in securities annually. See Bureau of the Pub. Debt, U.S. Dep't of the Treasury, Strategic Plan: Fiscal Years 2009-2014, at 8 (2008), available at http://www.publicdebt.treas.gov/whatwedo/bpdstrategicplan0914.pdf (on file with the Columbia Law Review) (describing Bureau's duties and authority).

133. U.S. Const. art. I, § 8, cl. 2.

134. See 2012 CRS Report, supra note 126, at 11-12 (noting default could lead to "a downgrade of the U.S. credit rating, an increase in federal and private borrowing costs, damage to the economic recovery, and broader disruptions to the financial system").

135. The issuance of potentially illegitimate debt could reduce investor confidence in the federal government's commitment to meet its obligations. A loss of investor 
fore, is that a president's attempt to avoid default on government obligations might cause precisely the real-world problem that it is designed to avoid.

The difference, however, is in degree. A straight default on obligations, especially debt payments, ends any pretense that the government is a reliable financial player. ${ }^{136}$ Issuing bonds of uncertain reliability will almost surely increase borrowing costs, but any such increase can be no more than the increase that would attend an up-front default.

Moreover, the underlying factors that could make the Presidential bonds less valuable are factors that would independently have even more catastrophic effects on the economy as a whole. If, even after failing to make an eleventh-hour compromise, Congress and the president still cannot come to an agreement to end the trilemma, then there will be reason to worry for the future of the nation. Even the regular budget process, which precedes the possible creation of any trilemmas, would be so broken that it would no longer permit the proper functioning of the government.

Accordingly, if the president had good reason to conclude that the market would demand intolerably high interest rates for Presidential bonds, then on that basis he might appropriately rule out ignoring the debt ceiling as the solution to the trilemma. But in such a scenario, it would be a policy consideration-the sub-junk status of the prospective Presidential bonds-rather than a constitutional consideration per se, that would take the issuance of new debt off the table. Conversely, however, if the president had good reason to believe that financial markets would only demand a tolerable interest premium for the Presidential bonds, so that issuing them would make financial sense, then our analysis suggests that this path should be constitutionally preferred because the key constitutional consideration-how much legislative power the president must usurp in order to carry out the solution-favors issuing new debt over canceling appropriations.

In addition, the one aspect of issuing debt that is not purely mechanical is, as noted above, the determination of the maturities of the debt securities. If the president decides to issue bonds on his own authority, he must decide (as, indeed, he must when issuing bonds under any circumstance) whether to issue long-term obligations, short-term obligations, or some combination of maturities. While our earlier argument with regard to unilateral spending cuts warned of the power of executive

confidence could result in much higher interest rates on the potentially illegitimate debt. See id. at 12 ("If creditors lost this confidence, the federal government's interest costs would likely increase substantially and there would likely be broader disruptions to financial markets.”).

136. Again, at least initially, the lack of confidence would not be based on any underlying economic reason, but solely because the political system is creating a false crisis and a wholly unnecessary trilemma for the President. Once the crisis takes hold, of course, the damage could spread to the real economy. 
discretion, such discretion in the context of debt issuance can work to the advantage of the nation. If the president determines, for example, that the financial markets will accept only short-term Presidential bonds, then he can choose to issue only such bonds. If, on the other hand, financial leaders were to inform the president that lenders would rather buy long-term bonds-perhaps on the theory that the budget process will have been long since healed ten years hence, with ex post commitment of the full faith and credit of the United States government to the Presidential bonds (converting them into standard Treasury bonds) then the president can act accordingly. We need make no judgment here about how the president should act. We simply note that the president, even when executing an extraordinary decision to issue bonds without congressional authorization, would retain only the type of discretion that he already possesses in his duties to manage the debt of the United States. This is far different from a president taking it upon himself to alter levels of spending.

In short, while unauthorized issuance of debt would hardly be ideal, and would carry with it risks of financial and economic disruption, it would be a more rational and administrable process-to say nothing of a more limited expansion of presidential discretion-than enacting unauthorized spending cuts. For this and other reasons, ${ }^{137}$ it would thus be a less unconstitutional ${ }^{138}$ course than unilateral presidential spending cuts, because rationality and administrability are not merely practical considerations; they may bear on constitutionality. Other things being equal, a presidential course of action in an area of congressional primacy is on firmer constitutional ground where the president can follow Congress's priorities, rather than having to fashion his own in order to act coherently.

3. When the President Increases Taxes. - Finally, what are the practical issues that would arise if the president resolved the trilemma by increasing taxes to levels above those authorized by Congress under the tax law? Taxes lie somewhere between debt and spending in terms of their heterogeneity. Asking a government to "borrow money" is a rather unambiguous request (again, other than certain technical matters, especially the maturity dates of the new debt). Asking it to "collect taxes" necessarily implicates a broader range of questions, covering the tax base (that

137. Wholly apart from considerations of rationality and administrability, ignoring the debt ceiling would be less unconstitutional than unilateral presidential spending cuts because the former, but not the latter, would ensure that the government did not violate Section 4 of the Fourteenth Amendment by failing to meet its legal obligation to pay its bills. Cf. U.S. Const. amend. XIV, § 4 . In addition, as we discussed above and elaborate more fully below, ignoring the debt ceiling best reflects what appear to be Congress's priorities. See supra Part II.A. III, infra.

138. We elaborate more fully on what we mean by degrees of constitutionality in Part 
is, what to tax), the rates of taxation, and the likelihood of tax evasion and avoidance.

Because of these unknowns, the decision to increase taxes necessarily confers powers upon the president (who, throughout this analysis, is assumed to be acting without the authority of Congress), with significant policy implications. For example, if the president decided to collect the necessary funds by increasing estate taxes, that would have quite different effects than if he authorized an increase in excise taxes.

Even so, increasing taxes appears to raise somewhat fewer issues of complexity than cutting spending. Collecting more money from people than they expected to pay might cause hardship, and it might unravel some transactions that would otherwise take place, but the tax collectors would not face all of the types of questions that budget cutters would face in the scenarios described above.

From a purely administrative standpoint, moreover, collecting more taxes is fully within the capacities of the agencies over which the president exercises authority. ${ }^{139} \mathrm{He}$ could, for example, simply instruct the tax authority to increase withholding on all regular paychecks, under the income tax or the Social Security and Medicare taxes. This process is fully automated, and the president's authorization would be all that was needed to collect additional funds. Some refusals to pay might follow, but because the employers withholding the taxes are not paying those taxes, the process could be expected to be administratively simple.

Deciding to increase the taxes that are easier to collect is, of course, a policy choice of its own. The burdens would not be shared equally. This would be one of many reasons that the president would be sure to face fierce political resistance to any attempt to increase taxes. The administrative simplicity, however, is a strong argument for increasing taxes, rather than cutting spending, in the event that the financial markets rule out the possibility of Presidential bonds.

139. See Elena Kagan, Presidential Administration, 114 Harv. L. Rev. 2245, 2329 (2001) ("Congress's delegations of power to the President logically coexist with a presumption that the President has ultimate control over all executive agency decisions.”). The Internal Revenue Service, which is responsible for collecting taxes, is a bureau of the Department of the Treasury-an executive department controlled by the president. 


\section{Prudential Issues Raised by the President's Choice}

The analysis above set aside many policy issues, focusing instead on the practical implications of each possible solution to the trilemma. At least as important, however, are the prudential questions that are raised by different types of unauthorized presidential actions. Such considerations suggest a different set of tradeoffs, based on the likely effects of a president's choice, both in the immediate crisis, and in the precedent that it would set for the country going forward.

The political branches of government are at their most political (in both good and bad senses) when taxing and spending are involved. While Congress has agreed over the years to delegate its authority to coin and regulate money, ${ }^{140}$ for example, it has never allowed technocratic agencies to determine the levels and types of taxes and spending that the government undertakes. Election campaigns are often fought over issues of taxes and spending, and any compromises are designed to trade off important priorities, benefits, and costs. ${ }^{141}$

When Congress agrees to a spending law, it therefore is making a statement about the importance of various choices, both absolutely and relatively. If Congress as a whole determines that there should be a certain level of social spending versus military spending, for example, it is almost surely true that each member of Congress would have preferred a different balance. The ultimate spending bill, therefore, represents in raw form the political balance of power in any given year.

Similarly, the tradeoffs involved in designing the tax laws are also deeply political. A senator who would prefer a pure consumption tax allows the income tax to continue, on the condition that certain types of saving are exempt from taxes. A believer in low corporate tax rates negotiates a compromise in which she allows somewhat higher rates, on the condition that the recognition of certain corporate income can be deferred. The nature and complexity of the political choices is limited only by the imaginations of the parties to the negotiations.

As the process of determining the budget and appropriations proceeds, putting the taxing and spending decisions together multiplies the ways in which the result is best viewed as a set of quid pro quos and

140. See Fed. Reserve Sys., Purposes, supra note 81, at 85 ("Each of the twelve Reserve Banks is authorized by the Federal Reserve Act to issue currency, and the Department of Treasury is authorized to issue coin.").

141. See William G. Jacoby, Public Attitudes Toward Government Spending, 38 Am. J. Pol. Sci. 336, 336 (1994) (noting government spending is "significant policy issue" in U.S. election campaigns); Susan A. MacManus, Taxing and Spending Politics: A Generational Perspective, 57 J. Pol. 607, 607 (1995) ("[T] axing and spending issues are increasingly at the forefront of most elections ....”); Gerald F. Seib, Taxes Emerge as Defining Issue for 2012 Campaign, Capital Journal, Wall St. J. (Sept. 19, 2011, 1:16 PM), http:/ /online.wsj.com/article/SB10001424053111903374004576580710594126704.html (on file with the Columbia Law Review) (arguing taxes are important issue in every election, but will be particularly significant in 2012 election because of nation's economic distress). 
understandings that each member of Congress expects to be honored. These tradeoffs and balances fully satisfy no one, of course, but they are hammered out in the atmosphere of a representative body that is constitutionally empowered to make just such difficult choices.

The debt ceiling could be viewed as merely part of this mixture of tradeoffs. When Congress passed the 2011 budget in spring 2011, ${ }^{142}$ perhaps it did so in the full knowledge that what its members were agreeing upon would never be enacted. If that were true, however, it would suggest that the debt ceiling was being used as a bait-and-switch mechanism, with one side acting in bad faith, never intending to honor the compromises over taxing and spending to which it had agreed.

In any event, the question posed by the trilemma is not whether the will of Congress might be frustrated by the president's choice about how to proceed. The key issue is which choice least threatens Congress's higher priorities. If Congress passes a budget that implies a level of borrowing, yet it also leaves in place prior legislation that purports to forbid that new level of borrowing, a president who ignores the debt ceiling will honor the most recent-and, we would argue, most important—of Congress's stated priorities, allowing the absolute and relative magnitudes of taxes and spending mandated by Congress to be carried out.

The worst that can happen in such a case is that Congress would need to undo the damage in a future budget. That is, if the president's guess is incorrect, and Congress's highest priority was to prevent the national debt from exceeding a certain dollar amount, then Congress has the power to pass budgets in future years with surpluses sufficient to return to the debt level that it prefers. ${ }^{143}$ The damage that might be wrought in the meantime, or by having to live under a more austere budget in future years than otherwise, is a cost of ignoring Congress's will today. The costs of allowing a president to violate the balance of Congress's priorities in taxing and spending, however, are much more difficult to undo because the departure from Congress's choices could create a dramatically different status quo, thus calling into play a new set of political forces. If Congress does not like the choices the president makes in canceling spending or raising taxes, the new reality may prevent it from putting people in the position that Congress intended when it passed its budget. ${ }^{144}$ That is, while it is straightforward to say, "we hereby

142. See Hook, supra note 118 (describing months of congressional conflicts leading up to passage of 2011 budget).

143. Indeed, as noted above, Congress can even prospectively couple a "hard" debt ceiling with a delegation to the president of the power to impound appropriated spending. See supra text accompanying notes 120-122.

144. In an important article, Professors Eskridge and Ferejohn explained how judicial and administrative constructions of statutes can change the legal status quo against which the vector sum of political forces in Congress operates. See generally William N. Eskridge, Jr. \& John Ferejohn, The Article I, Section 7 Game, 80 Geo. L.J. 523 (1992). Our 
decree that the national debt should be reduced back to $\$ X$ trillion," and then to pass legislation and retire outstanding debt to make it so, it is much more difficult (and, perhaps, impossible in many instances) to restore the status quo ante for people whose taxes were increased by the president, or who failed to receive particular benefits under the president's discretionary spending cuts. (Again, refunding tax payments, or honoring contractual obligations long after benefits were due, does not guarantee that people will be restored to the state in which Congress intended them to be.) Just as legislation can be sticky, ${ }^{145}$ so too can acts taken by the president that usurp legislative power.

Finally, the prudential tradeoffs inherent in the trilemma can be framed as a question of how much power each choice confers on the president. Or, to put it in partisan political terms, which choice would be the least worrisome from the standpoint of a member of Congress who is not from the president's party? While reasonable people might offer different answers to that question, giving the president the power with the least latitude-and that is most easily reversed-strikes us as the prudent choice, no matter which parties control the various political bodies. For the foregoing reasons, it seems clear that the president would minimize his assumption of power by issuing debt rather than rebalancing taxing and spending choices.

\section{E. The Hierarchy of Choices}

Our analysis, therefore, is not designed to favor one party or ideology over another. We believe that anyone who values the separation of powers, and who wishes to protect Congress's prerogatives under the Constitution, would be best served in the first instance by making sure that no president is ever faced with such a choice. If the political system fails, however, the president can best honor the balances inherent in the Constitution by ignoring the debt ceiling.

But as we noted above, markets could react so badly to the prospect of Presidential bonds as to reduce the president's trilemma to a dilemma: unilaterally cut spending or raise taxes. Which of these options would be less unconstitutional? Surprisingly, our hierarchy of choices tentatively suggests that the president's second-least-bad choice would be to raise taxes. In addition to the administrative advantages noted above, raising taxes rather than cutting spending would not shortchange persons who are legally entitled to government funds. Thus, raising taxes, like ignoring the debt ceiling, avoids a violation of Section 4 of the Fourteenth

point here is that a presidential decision to cancel spending or impose taxes can be equally or more disruptive and can preclude a congressional "fix" in much the same way.

145. See Eric A. Posner \& Adrian Vermeule, Legislative Entrenchment: A Reappraisal, 111 Yale L.J. 1665, 1667-69 (2002) (discussing possibility of "entrenching statutes," which cannot be changed by subsequent legislation). 
Amendment, ${ }^{146}$ whereas spending cuts, depending on their size and apportionment, could violate Section 4 in addition to the separation of powers.

It is curious that during the summer of 2011 so many commentators and politicians considered the choice to cut spending as not merely the least bad choice, but actually as a constitutionally valid choice. ${ }^{147} \mathrm{We}$, by contrast, recognize that all of the president's choices would be unconstitutional and we believe that the worst choice would be for the president to seek to cut spending below the levels authorized by Congress.

What explains this difference in perspective? Candidly, this Article's conclusion about the relative constitutional merits of the president's unilaterally cutting spending versus raising taxes is substantially less certain than our conclusion that ignoring the debt ceiling is less bad than either of the other options. After all, the tax code is filled with deductions and credits that serve the same economic function as spending, ${ }^{148}$ and so increases in taxes, even when easier to administer than cuts in spending, may implicate the very same sorts of policy tradeoffs. From the perspective of separation of powers, therefore, the two could be seen as equally unconstitutional.

In addition, there is a palpable sense that unilateral increases in taxes by the president are unthinkable in a way that unilateral spending cuts by the president are not. ${ }^{149}$ We fully acknowledge that, as noted above, this sense that a president just can't do that would certainly constrain the president from raising taxes as a matter of politics. Still, it is not clear that this political constraint is a constitutional constraint.

To be sure, longstanding practice is an important factor in constitutional interpretation, and while there are instances in U.S. history of presidents spending less money than Congress appropriated, ${ }^{150}$ there is

146. U.S. Const. amend. XIV, $\S 4$.

147. See Binyamin Appelbaum, Debt Ceiling Has Some Give, Until Roof Falls In, N.Y. Times, May 5, 2011, at A1 (noting Republican plan to prioritize interest payments if debt limit is reached necessarily requires spending cuts); Carl Hulse, Boehner Outlines Demands on Debt Limit Fight, N.Y. Times, May 10, 2011, at A16 (reporting Speaker Boehner demands "trillions of dollars in federal spending cuts in exchange for [Republican] support of an increase in the federal debt limit"); Jim Demint, More Spending Is a Threat to America, Politico (Jan. 24, 2011, 4:50 AM), http://www.politico .com/news/stories/0111/48020.html (on file with the Columbia Law Review) (suggesting government spending is greater threat to full faith and credit of United States than increasing debt limit).

148. See Stanley S. Surrey, Tax Incentives as a Device for Implementing Government Policy: A Comparison with Direct Government Expenditures, 83 Harv. L. Rev. 705, 706-07 (1970) (explaining tax expenditures are similar to direct spending because they promote governmental aims, and giving examples of tax expenditures found in tax laws).

149. See supra text accompanying notes 40-44; see also MacManus, supra note 141, at 623 (discussing survey of different age groups showing "all age groups overwhelmingly prefer spending cuts to tax increases").

150. See supra notes $45-47$ and accompanying text. 
no history of presidents raising taxes. But there is less to this point than meets the eye, because there is no history of presidents spending less money than Congress appropriated, when Congress has required that the appropriated sums be fully spent. ${ }^{151}$

Thus, we will stick with our tentative conclusion that, if faced with the dilemma of unconstitutionally raising taxes or unconstitutionally cutting spending, the president would act less unconstitutionally by raising taxes. We are substantially more confident in our conclusion that he would act still less unconstitutionally by ignoring the debt ceiling, so long as the bond markets cooperated sufficiently to convert the dilemma into a trilemma.

By now, however, readers may be wondering exactly what we mean when we say that one course of action is more or less unconstitutional than another. Isn't constitutionality an on/off condition, like pregnancy? We hope that the discussion so far shows why the answer is no. In the next Part, we build on the foregoing analysis to develop a more general account of degrees of unconstitutionality.

\section{Beyond the Debt Ceiling: The General Problem of No CONSTITUTIONAL OPTIONS}

The prior Parts of this Article conceptualized the choice President Obama nearly faced in the summer of 2011 as a choice among unconstitutional options. We also offered views about how a president ought to choose among the particular unconstitutional options of unilaterally raising taxes, unilaterally cutting spending, and unilaterally issuing debt. Readers may disagree with our ordinal rankings. Readers may even disa-

151. We acknowledge that the original understanding also strongly cuts against the president unilaterally raising taxes. The Framers were no doubt aware of the longstanding parliamentary condemnation of efforts by English kings to collect taxes without legislative authorization and disapproved on grounds that can be roughly translated into the American constitutional context. See Josh Chafetz, Impeachment and Assassination, 95 Minn. L. Rev. 347, 367-83 (2010) (discussing reign of Charles I and how it was seen by Benjamin Franklin); Tribe, Debt Ceiling, supra note 74 (discussing King John's promise to lords, in Magna Carta, that taxation would not occur without "common counsel of our kingdom," as well as condemnation, in English Bill of Rights of 1689, of efforts by James II to tax by royal prerogative). But this fact only provides a further reason why a president's efforts to raise taxes unilaterally would be unconstitutional, which we freely admit. The question is whether it would be more or less unconstitutional than a president's efforts to cut spending unilaterally. On that point, the original understanding is at least somewhat ambivalent, for it also provides grounds for condemning a president's unilateral spending cuts. Justice Kennedy's concurrence in Clinton v. City of New York contains ample citations to Founding-era documents in sounding its warning of the dangers of permitting the president to make spending cuts on his own. 524 U.S. 417, 449-53 (1998) (Kennedy, J., concurring). Meanwhile, if we ask what contemporary Americans would regard as the paradigmatic example of executive usurpation, we think they would more likely point to President Nixon's behavior during the impoundment crisis (and more broadly) than to seventeenth-century (or earlier) English history. 
gree with our contention that the only realistic options during the debt ceiling crisis were all unconstitutional. But we hope that most readers will agree with us that the general problem warrants further consideration. In this Part, we analyze the problem in general terms: How should government officials choose among unconstitutional options?

One might think that when faced with no constitutional options, the president (or some other legal actor) is freed from constitutional constraint, at least when the president (or other legal actor) has not himself created the circumstances necessitating a fateful choice. For concreteness, suppose that Congress had failed to raise the debt ceiling in the summer of 2011 and that Congress alone bore responsibility for that failure. President Obama might then have reasoned as follows: Congress has put me in the untenable position of having to violate the Constitution, so Congress cannot now be heard to complain if I usurp one, rather than another, of its powers. While this sentiment is somewhat compelling, ${ }^{152}$ it is ultimately wrong, and dangerously so.

The costs of constitutional violations will be borne by the people, not just Congress, both in a practical sense-because people will be required to forgo payments or pay higher taxes now or in the future-and in a constitutional sense-because structural constitutional provisions ultimately serve the people, not the institutions they directly protect. ${ }^{153}$ Thus, even when Congress has wholly avoidably created a constitutional trilemma (or other multi-lemma) for the president, he cannot use that fact as a reason to, in effect, punish the people.

Furthermore, the "all bets are off" line of reasoning has no logical stopping point. If the necessity of violating the Constitution in some way empowers the president to violate the Constitution in any way, then a constitutional multi-lemma gives the president potentially unlimited power. To stick with the debt ceiling example, he could, in violation of the constitutional allocation of war-making powers, ${ }^{154}$ unilaterally order the armed forces to invade Venezuela or Iran, sell its oil on the world market, and use the proceeds to make up any shortfall between appropriations and revenues from authorized taxing and borrowing. He could, in violation of Alaska's equal suffrage in the Senate (and other constitutional limits), ${ }^{155}$ sell Alaska back to Russia. And so forth. It is clear from

152. Below, we explain that reasoning of this sort may warrant the conclusion that the courts generally should treat a political actor's choice among unconstitutional options as presenting a nonjusticiable political question. See infra text accompanying note 234 .

153. See Bond v. United States, 131 S. Ct. 2355, 2364 (2011) ("States are not the sole intended beneficiaries of federalism. An individual has a direct interest in objecting to laws that upset the constitutional balance between the National Government and the States . . . Fidelity to principles of federalism is not for the States alone to vindicate.”).

154. U.S. Const. art. I, § 8, cl. 11-18.

155. See, e.g., id. art. IV, § 4; id. amend. XVII. 
these and other examples that might be adduced that not all constitutional violations are equivalent.

Once one recognizes that some constitutional violations are worse than others, however, there arises the difficult question of developing metrics for comparison. We do not attempt to formulate an algorithm but we state some general principles. This Part elucidates three criteria to guide the choice among unconstitutional options: minimize the unconstitutional assumption of power; minimize sub-constitutional harm; and preserve, to the extent possible, each party's own ability, and the ability of other actors, to undo or remedy constitutional violations.

From where do we derive these criteria? Partly they emerge from our discussion of the debt ceiling crisis and other examples. In addition, they are implicit in the one episode of American history when a president admitted the possibility that he might have to choose a course of action from solely unconstitutional options.

The relevant discussion appears in President Abraham Lincoln's address to a special session of Congress in July 1861. In late April, President Lincoln had ordered the privilege of the writ of habeas corpus suspended between Washington, D.C., and Philadelphia. ${ }^{156}$ When that order was carried out, Chief Justice Taney declared the presidential suspension unconstitutional, ${ }^{157}$ but the writ he issued was ignored. Speaking to Congress a little over a month later, President Lincoln argued that his suspension order was constitutional, ${ }^{158}$ but before coming to that point he claimed that even if Congress alone had the power to suspend the privilege of the writ, an unconstitutional presidential suspension was nonetheless justified as the least unconstitutional option available. He asked rhetorically, "are all the laws, but one, to go unexecuted, and the government itself go to pieces, lest that one be violated?"159

It is clear from the context that the one "law" that warranted violation in President Lincoln's hypothetical example was a constitutional provision: the Suspension Clause. But Lincoln implied that failure to violate the Suspension Clause would be a greater violation of the

156. Letter from Abraham Lincoln, President, to Winfield Scott, Commanding General, U.S. Army (Apr. 27, 1861), in 4 The Collected Works of Abraham Lincoln 347, 347 (Roy P. Basler ed., 1953) [hereinafter Collected Works of Lincoln].

157. Ex parte Merryman, 17 F. Cas. 144, 149 (Taney, Circuit Justice, C.C.D. Md. 1861) (No. 9,487).

158. See Abraham Lincoln, President, Message to Congress in Special Session (July 4, 1861) [hereinafter Lincoln, Message to Congress], in Collected Works of Lincoln, supra note 156, at 421, 430-31 (noting, among other things, Suspension Clause of Article I, Section 9 does not specify what actor may suspend the privilege of the writ when "in Cases of Rebellion ... the public Safety may require it” (quoting U.S. Const. art. 1, § 9, cl. 2)) .

159. Id. at 430. 
Constitution, as it would betray the Presidential Oath, ${ }^{160}$ which requires the president to "preserve, protect and defend the Constitution of the United States."

We do not claim that Lincoln was correct that his Oath required him to suspend the privilege of the writ in order to save the Union. There may well have been actions short of unilateral suspension that would have protected national security as effectively. Moreover, real dangers lurk in presidential assertions of an unlimited constitutional duty to preserve national security as a basis for overriding clear constitutional limits. Accordingly, one can think that Lincoln erroneously concluded that he faced a genuine conflict between constitutional imperatives. However, assuming arguendo that he did face such a conflict, his method of resolving the conflict is instructive.

President Lincoln more or less articulated our three criteria for choosing among unconstitutional options. First, he contended that presidential suspension, even if assumed unconstitutional, would be less unconstitutional than the dissolution of the Union. Second, in invoking the possibility that "the government itself [might] go to pieces," Lincoln was not merely invoking a constitutional harm but the sub-constitutional harms that would follow from dissolution of the Union, which he balanced against what he thought would be the substantially smaller harm to liberty from suspension. ${ }^{162}$ Third, President Lincoln presented his resolution of the issue for the possibility of congressional reconsideration, ${ }^{163}$ thus observing the third principle: preservation of the power of other actors to remedy or undo constitutional violations.

In addition to the doubts we have raised about whether President Lincoln faced a genuine conflict, reasonable minds can differ over whether he correctly applied the three principles, just as they can differ over our proposed application of the same principles to the debt ceiling case. But we hope that the principles themselves will command broad assent. After explaining why the problem of having no constitutional options is less rare than one might think, the balance of this Part elucidates the three principles for addressing that problem.

160. See id. (" $[\mathrm{W}]$ ould not the official oath be broken, if the government should be overthrown, when it was believed that disregarding the single law, would tend to preserve it?").

161. U.S. Const. art. II, § 1, cl. 8.

162. See Lincoln, Message to Congress, supra note 158, at 430 (contending privilege of writ of habeas corpus "relieves more of the guilty, than of the innocent" and would only be violated by presidential suspension "to a very limited extent").

163. See id. at 431 ("Whether there shall be any legislation upon the subject, and if any, what, is submitted entirely to the better judgment of Congress."). 


\section{A. The Scope of the Problem}

There is virtually no legal doctrine governing the choice among unconstitutional options. That absence partly reflects the fact that the Constitution's commands are almost entirely negative, forbidding rather than requiring certain actions. For example, government officials may not deprive persons of life, liberty or property without due process, but they generally need not take any affirmative steps to provide persons with various protections and benefits. ${ }^{164}$ Accordingly, when faced with the temptation to act unconstitutionally, government actors can usually satisfy the Constitution by simply doing nothing.

However, government actors sometimes labor under affirmative duties. Two such duties were at issue in the debt ceiling crisis. The Take Care Clause imposes one duty. The president's duty to take care that the laws are faithfully executed is best understood as an affirmative duty to execute the law. ${ }^{165}$ Thus, although justiciability doctrines limit the ability of private parties to seek court orders to the Administration to carry out the law, ${ }^{166}$ the duty exists nonetheless. A president who refused to execute some law would, at a minimum, need to explain to the public (and perhaps to members of Congress seeking to impeach him) that the law is either unconstitutional ${ }^{167}$ or that refusal to execute the law in some set of circumstances was a valid exercise of prosecutorial discretion. ${ }^{168}$ Simple

164. See, e.g., Rust v. Sullivan, 500 U.S. 173, 201 (1991) ("The Government has no affirmative duty to commit any resources to facilitating abortions ...." (internal quotation marks and citations omitted)); DeShaney v. Winnebago Cnty. Dep't of Soc. Servs., 489 U.S. 189, 195 (1989) (" $[\mathrm{N}]$ othing in the language of the Due Process Clause itself requires the State to protect the life, liberty, and property of its citizens against invasion by private actors.").

165. See Cass R. Sunstein, Standing and the Privatization of Public Law, 88 Colum. L. Rev. 1432, 1471 (1988) ("The 'take Care' clause, however, is a duty, not a license. The clause requires the President to carry out the law as enacted by Congress.").

166. See Lujan v. Defenders of Wildlife, 504 U.S. 555, 568-69 (1992) (opinion of Scalia, J.) (““ $[S]$ uits challenging . . . the particular programs agencies establish to carry out their legal obligations [are] rarely if ever appropriate for federal-court adjudication." (quoting Allen v. Wright, 468 U.S. 737, 759-60 (1984))).

167. See Presidential Authority to Decline to Execute Unconstitutional Statutes, 18 Op. O.L.C. 199, 201 (1994) ("Where the President believes that an enactment [is unconstitutional], he has the authority to defend his office and decline to abide by it ....").

168. See Jack Goldsmith \& John F. Manning, The President's Completion Power, 115 Yale L.J. 2280, 2293 (2006) ("[The judiciary is reluctant] to review prosecutorial decisions [because of] the background constitutional premise that the exercise of such discretion is 'a special province of the Executive." (quoting Reno v. Am.-Arab Anti-Discrimination Comm., 525 U.S. 471, 489 (1999))). 
nonenforcement would be, prima facie, a breach of constitutional duty. ${ }^{169}$

Section 4 of the Fourteenth Amendment indicates another affirmative duty of the president. Suppose that some bonds or other government bills came due. Suppose further that, under the best interpretation of Section 4, failure to pay the bondholders and other bill submitters would call into question the public debt, and thus violate Section 4 . That conclusion is a conclusion that Section 4 imposes an affirmative obligation. Phrased in the passive voice ("shall not be questioned"), ${ }^{170}$ the provision's language draws no distinction between acts that would call the public debt into question and omissions that would do so. Indeed, one would expect that in the usual course Section 4 would most frequently apply to omissions (namely, failures to pay).

Nor is the president the only government actor with affirmative obligations under the Constitution. For example, government officials have affirmative duties to persons in their custody, such as prisoners. ${ }^{171}$

Or consider the situation of a trial judge faced with a request by a criminal defendant to restrict press access to courtroom proceedings in some way in order to guarantee a fair trial. Doing nothing is not in any meaningful sense an option. To be sure, the trial judge could order that the indictment be dismissed on the ground that there is no way to fully honor both the defendant's Sixth Amendment rights and the First Amendment rights of the press. In a sense, that would be doing nothing. But we think-and as we explain below, the courts think-that this is too high a price to pay to avoid choosing the lesser constitutional evil.

In light of the fact that government actors will, from time to time, need to choose among unconstitutional options, how should they make that choice? We next elaborate three salient principles.

\section{B. Minimize the Unconstitutional Assumption of Power}

In our discussion of the practical dimensions of the various horns of the trilemma in Part II, we noted how a presidential decision to ignore the debt ceiling would require a smaller exercise of distinctively policy judgment than would be required by a decision to cut spending or raise taxes. That factor matters for the comparative constitutional analysis because of the nature of the underlying violations. Any presidential decision to tax, borrow, or spend (or not spend) without congressional

169. See Nat'l Treasury Emps. Union v. Nixon, 492 F.2d 587, 604 (D.C. Cir. 1974) ("Article II, Section $3 \ldots$ does not permit the President to refrain from executing laws duly enacted by the Congress as those laws are construed by the judiciary.").

170. U.S. Const. amend. XIV, $\$ 4$.

171. See Farmer v. Brennan, 511 U.S. 825, 833 (1994) (““[P]rison officials have a duty . . to protect prisoners from violence . . .." (quoting Cortes-Quinones v. JiminezNettleship, 842 F.2d 556, 558 (1st Cir. 1988))); Estelle v. Gamble, 429 U.S. 97, 102-04 (1976) (holding prison officials have obligation to provide medical care to prisoners). 
authorization violates the principle of separation of powers because the powers to tax, to borrow, and to spend (or not spend) are all allocated to Congress, not the president. ${ }^{172}$ But in so allocating power, the Constitution also allocates to Congress the power to make the innumerable policy tradeoffs and compromises that go into a budget. ${ }^{173}$ Indeed, one could readily say that the Constitution allocates to the most representative branch of the federal government the powers to tax, borrow, and spend precisely because the exercise of these powers involves inherently political choices.

One might plausibly disagree with our conclusion that the president assumes more legislative policy power when he unilaterally cuts spending than when he unilaterally raises taxes. One could even disagree with our conclusion that the president assumes more legislative policy power when he unilaterally cuts spending or raises taxes than when he unilaterally issues Presidential bonds. But we hope that no one will disagree with our underlying view that, other things being equal, as between two ways of unilaterally exercising legislative power in violation of the Constitution, the president should choose the course in which he unconstitutionally exercises less legislative power.

In choosing whether to usurp the legislative power to borrow, tax, or (not) spend, the president apparently faces a choice among roughly commensurable constitutional violations. Each power is allocated to Congress, and so the president compares apples to apples in choosing whether the constitutional balance of power will be more or less upset by his unilateral exercise of one rather than another power.

Yet the actions in question are not exactly commensurate: One might think that taxing is somehow more quintessentially a legislative power than borrowing or spending, ${ }^{174}$ in which case one might conclude (contrary to our own tentative conclusion in Part II) that the constitu-

172. See, e.g., U.S. Const. art. I, §8, cl. 1-2; id. art. I, § 9, cl. 7; 2 Joseph Story, Commentaries on the Constitution of the United States $\$ \$ 903-908,1051$ (Boston, Hilliard, Gray \& Co. 1833) (discussing Congress's powers to tax, borrow, and spend); see also Clinton L. Rossiter, Constitutional Dictatorship: Crisis Government in Modern Democracies 226-27 (1948) (discussing President Lincoln's unauthorized advancement of two million dollars of unappropriated funds to three private citizens).

173. See Stephen E. Frantzich \& Claude Berube, Congress: Games and Strategies 9 (4th ed. 2010) (discussing importance of persuasion and compromise in congressional coalition building); James J. Gosling, Economics, Politics, and American Public Policy 64 (2008) (noting Congress's choices in budgetary process "represent an amalgam of compromises and accommodations that have presidential initiatives as their starting point").

174. See Erwin Chemerinsky, The Conservative Assault on the Constitution 77 (2010) ("Article I of the Constitution gives Congress the power to tax and spend and this always has been regarded as a quintessential legislative power."); The Federalist No. 33, at 159 (Alexander Hamilton) (George W. Carey \& James McClellan eds., 2001) (describing power to tax as "the most important of the authorities proposed to be conferred upon the Union"). 
tionally worst option would be for the president to unilaterally raise taxes. Further, depending on which unilateral course the president chooses, he might violate constitutional provisions beyond separation of powers. As we discussed in Part II, a presidential decision unilaterally cutting spending would potentially violate Section 4 of the Fourteenth Amendment as well as separation of powers. Meanwhile, a presidential decision to unilaterally raise taxes could be said to violate the provision of Article I requiring that bills raising revenue must originate in the House of Representatives. ${ }^{175}$ There is no agreed-upon metric for aggregating and weighing these respective constitutional violations. Indeed, with the notable exception of President Lincoln's all-the-laws-but-one speech, there does not even appear to be any awareness of the potential problem.

Our analysis proceeds by considering real and imaginary examples. Suppose first that Congress purported to "solve" the debt ceiling impasse by raising the debt ceiling by an amount insufficient to cover the existing shortfall, but that, in violation of the Takings Clause ${ }^{176}$ and (maybe) the Bill of Attainder Clause, ${ }^{177}$ Congress made up the difference by including in the same bill a measure confiscating the holdings of a small number of extremely wealthy individuals named in the bill. Could the president sign the bill on the theory that violating the Takings Clause and (maybe) the Bill of Attainder Clause would be no worse than usurping legislative power, as he would have to do under the trilemma if he vetoed the legislation? Or, conversely, is it categorically worse to violate two constitutional provisions or doctrines - the Takings Clause and the Bill of Attainder Clause-than to violate just one-the separation of powers doctrine? Would the confiscation plan be constitutionally equivalent to unilateral presidential action cutting spending because each action involves two distinct constitutional violations?

We would reject the notion that the key question is the number of constitutional provisions at stake. Perhaps if other things were equal, then one could say that it is worse to violate $n+1$ constitutional provisions than to violate $n$ constitutional provisions. But more broadly, any measure of comparative constitutional harm should be qualitative, not quantitative-or at least not merely quantitative.

Next consider an admittedly fanciful example. Suppose a criminal madman slips undetected into the Oval Office and, holding a loaded gun to the head of the president, orders him either (1) to instruct FBI agents to perform a warrantless search of the home of the criminal's ex-wife and charge her with possession of obscenity when they find a copy of Lady Chatterley's Lover, or (2) to unilaterally declare war on Iran and order a

175. U.S. Const. art. I, $\S 7$, cl. 1.

176. Id. amend. V.

177. Id. art. I, § 9, cl. 3 . 
nuclear strike against Tehran. Assuming the president is unwilling to take a bullet for the Constitution (as the consequence of a refusal to make a choice), ${ }^{178}$ we think it fairly clear that the president should choose option (1). Option (1) is not only less harmful than option (2), but also less unconstitutional, even though option (1) involves violating two constitutional provisions (the Fourth and First Amendments), whereas option (2) only involves violating one (the allocation to Congress of the power to declare war). ${ }^{179}$ We recognize, however, that we have not yet fully unpacked exactly what we mean by "less unconstitutional." For now, we are relying on what we expect will be broadly shared intuitions.

Those same shared intuitions also undercut any suggestion that rights are trumps ${ }^{180}$ in the sense that one should always prefer violating some non-rights provision to violating a rights provision. Rights may be trumps in the sense that they prevail against most utilitarian goals, ${ }^{181}$ but they are not trumps in the sense that they always prevail against other (non-rights) constitutional provisions. Indeed, constitutional doctrine allows that rights can generally be overridden by laws that are narrowly tailored to serve compelling interests, ${ }^{182}$ whereas most non-rights provisions do not appear to permit such overrides. For example, the legislative veto is not permitted even if it is narrowly tailored to serve a compelling

178. In the next section, we shall have more to say about whether the president or other government official must always choose a constitutional option, if available, even if the only constitutional options are catastrophic. For now, readers who think that the president should simply refuse to choose should imagine a variant on the hypothetical example in which the madman informs the president that if the president refuses to choose either option, the madman-who is, among his other talents, an excellent mimicwill impersonate the president and order both the violation of the rights of the madman's ex-wife and the nuclear strike on Tehran. Thus, in this modified example, failure to choose itself leads to unconstitutional actions.

179. U.S. Const. art. I, $\S 8$, cl. 11.

180. See Ronald Dworkin, Taking Rights Seriously, at xi-xv, 367 (1977) (describing political rights as "trumps" that exist when "a collective goal is not a sufficient justification for denying them what they wish, as individuals, to have or to do, or not a sufficient justification for imposing some loss or injury upon them”).

181. See Ronald Dworkin, A Matter of Principle 370 (1985) (developing equalitybased theory in which certain "rights should be accepted as trumps over utility, if utility is accepted ... as the proper background justification").

182. For this reason, Professor Schauer has aptly stated that rights are better understood as shields rather than trumps. See Frederick Schauer, A Comment on the Structure of Rights, 27 Ga. L. Rev. 415, 429-30 (1993) (arguing rights "protect against certain low justification ... efforts to restrict the activities that the rights are rights to, but do not protect against high justification ... efforts to restrict those activities"). 
interest, ${ }^{183}$ whereas a law that abridges freedom of speech or uses a suspect classification would be valid if it had that characteristic. ${ }^{184}$

That difference suggests that perhaps the opposite presumption should apply. In other words, perhaps nonderogable constitutional provisions (like the Article I, Section 7 requirements at issue in the line-item veto case ${ }^{185}$ ) should generally prevail over derogable ones (like the rights to free speech and to equal protection). We think that there may be a limited sense in which such a presumption in fact makes sense: Complying with separation of powers, federalism, or other non-derogable constitutional limits could, in principle, be the sort of compelling interest that justifies use of a race-based classification or a content-based regulation of speech. ${ }^{186}$

But one must be careful not to run too far with this line of analysis. Although saving the president's life certainly counts as a compelling interest, we do not think it would be accurate to say that it is therefore constitutionally permissible for the president to order the FBI to charge the gun-wielding madman's ex-wife with obscenity for possessing nonobscene materials. First Amendment doctrine is nonderogable on this particular: It does not utilize the compelling interest test to determine what qualifies as obscenity. ${ }^{187}$ Likewise, neither is doctrine under the Fourth Amendment, the other rights provision in this hypothetical case, exactly derogable. To be sure, there are exceptions to the warrant requirement, and some of them-such as the exigent circumstances exception $^{188}$ - are based on compelling interests, but the doctrine does not directly ask in particular cases whether to sacrifice the right for the sake of a compelling interest. ${ }^{189}$ So the possibility of using existing doctrine under a constitutional right to accommodate a structural constitutional provision will not always be available.

183. See INS v. Chadha, 462 U.S. 919, 959 (1983) (holding congressional veto unconstitutional).

184. See, e.g., Hill v. Colorado, 530 U.S. 703, 725-26 (2000) (upholding as constitutional Colorado criminal statute prohibiting individuals from knowingly approaching within eight feet of another person near health care facilities without that person's consent, because it served significant government interests and was narrowly tailored toward those interests).

185. Clinton v. City of New York, 524 U.S. 417 (1998).

186. Cf. Ricci v. DeStefano, 129 S. Ct. 2658, 2677, 2681 (2009) (stating compliance with Title VII could be compelling interest justifying presumptively impermissible raceconscious public employment measures).

187. See generally Miller v. California, 413 U.S. 15, 24-25 (1973) (discussing standard for identifying obscenity); Roth v. United States, 354 U.S. 476, 489 (1957) (same).

188. See, e.g., Kentucky v. King, 131 S. Ct. 1849, 1857-58 (2011) (discussing exigent circumstances exception to general requirement that warrant be obtained prior to search).

189. Id. at $1858-60$. 
Moreover, even when a right can be overridden by a compelling interest, the doctrine assumes that overriding the right is necessary to achieve that compelling interest in some non-fortuitous way. ${ }^{190}$ Yet the gun to the head of the president bears the wrong sort of causal relationship to any benefit that would derive from charging the madman's exwife with obscenity for such a charge to qualify as narrowly tailored to advancing a compelling interest. We think that in our hypothetical example, it is more straightforward and more accurate to say that the madman creates a choice for the president between unconstitutional options. To characterize one option as valid by virtue of the fact that it enables the president to avoid the other option is to omit the key step in the process: deciding which option is worse. We shall return to this characterization issue in Part III.C below.

For now, we want to note the seemingly irreducible mushiness of any plausible test for degrees of unconstitutionality. It is easier to state what the test should not be than what it should be. As noted above, the test should not simply count the number of constitutional violations. Nor do we think that there can be any all-purpose hierarchy of constitutional provisions. To use an example to which we shall return below, it may be tempting to say that the First Amendment is more important than the Sixth Amendment or vice-versa, but nothing in the constitutional text or our history provides a basis for either judgment. ${ }^{191}$ One can imagine circumstances in which the values underlying one provision prevail over those underlying the other, as well as vice-versa.

To make that last point concrete, suppose that the gun-wielding madman has different priorities. Suppose that he offers the president the following choice: (1) send the FBI to the home of a potential whistleblower with instructions to seize and destroy documents exposing highlevel government corruption; ${ }^{192}$ or (2) approve, and then act upon, a Justice Department legal memorandum asserting that American support for Libyan rebels in their resistance against the Gadhafi regime can continue without notification to Congress under the War Powers Act. ${ }^{193}$ Even

190. See, e.g., Sorrell v. IMS Health Inc., 131 S. Ct. 2653, 2668 (2011) (overturning Vermont law prohibiting pharmacies and other entities from selling prescriber-identifying information without prescriber's consent on grounds that law was not narrowly tailored to compelling state interests in improved public health and reduced healthcare costs).

191. See Neb. Press Ass'n v. Stuart, 427 U.S. 539, 561 (1976) ("The authors of the Bill of Rights did not undertake to assign priorities as between First Amendment and Sixth Amendment rights, ranking one as superior to the other.").

192. This scenario is not very different from what President Nixon ordered with respect to Daniel Ellsberg, except of course that no one was holding a gun to Nixon's head at the time. See Egil Krogh, The Break-In That History Forgot, N.Y. Times, June 30, 2007, at A17.

193. Auth. To Use Military Force in Libya, 35 Op. O.L.C. (Apr. 1, 2011) (release at 1), available at http://www.justice.gov/olc/2011/authority-military-use-in-libya.pdf (on file with the Columbia Law Review) ("We concluded that the President had the constitutional 
assuming that the president believes that option (2) would usurp the wardeclaring power of Congress, he could nonetheless fairly conclude that option (2) is less unconstitutional than option (1) because the abuse of power entailed by (1) makes the violations of the Fourth and First Amendments worse in this case. Comparing this conclusion with the conclusion we reached with respect to the first set of choices discussed above in the original gun-wielding madman scenario, we see that the question whether one unconstitutional option is more or less unconstitutional than another can yield different answers in different circumstances, even when the exact same constitutional provisions are in play. ${ }^{194}$

Does that mean that the entire enterprise of comparing unconstitutional courses of action is utterly mysterious? Not necessarily. To say that one cannot devise an all-purpose formula for weighing constitutional harms against one another is not to say that the enterprise is hopelessly subjective. We think that the sorts of factors that might be invoked in particular circumstances will often garner consensus. Indeed, we are familiar with courts and political actors making the relevant sorts of judgments, even if we are unaccustomed to thinking of them in the terms described in this Article.

Consider the choice courts must make in deciding whether to adopt a proposed narrowing construction of a statute in order to avoid a difficult constitutional question. On the one hand, courts try to construe statutes so that they are constitutional, because invalidating a statute is a serious affront to the democratic will as expressed through the legislature ${ }^{195}$ On the other hand, courts will not wholly rewrite statutes in order to avoid difficult constitutional questions, because such rewriting is a different sort of affront to the democratic will, insofar as it usurps the legislative function. ${ }^{196}$ Which affront is worse? The cases do not give a

authority to direct the use of force in Libya .... We also advised that prior congressional approval was not constitutionally required to use military force in the limited operations under consideration."). This Article assumes for purposes of this hypothetical example that the gun-wielding madman threatens the president before the Gadhafi regime has been displaced.

194. Our examples are purely illustrative. Thus, we invite readers who reach other conclusions with respect to our scenarios to imagine their own scenarios in which the answer to the question whether one or another constitutional provision prevails in a conflict changes based on the context.

195. See, e.g., Crowell v. Benson, 285 U.S. 22, 62 (1932) ("When the validity of an act of the Congress is . . . in question ... even if a serious doubt of constitutionality is raised, it is a cardinal principle that this Court will first ascertain whether a construction of the statute is fairly possible by which the question may be avoided.").

196. See, e.g., United States v. Stevens, 130 S. Ct. 1577, 1591-92 (2010) (refusing to rewrite statute "for doing so would constitute a 'serious invasion of the legislative domain,' and sharply diminish Congress' 'incentive to draft a narrowly tailored law in the first place." (citations omitted) (quoting United States v. Treasury Emps. Union, 513 U.S. 454, 479 n.26 (1995); Osborne v. Ohio, 495 U.S. 103, 121 (1990))); Reno v. ACLU, 521 U.S. 844, 884-85 (1997) ("This Court "will not rewrite a . . law to conform it to constitutional 
categorical answer, instead applying context-specific judgment to allow creative interpretation but not rewriting. While there is no sharp boundary line between those activities, there can be consensus about a great many cases that fall on one or the other side of the boundary.

We think the same should be true about choices among unconstitutional options. In our discussion of the debt-ceiling crisis in Part II, we gave context-specific reasons why a presidential decision simply to ignore the debt ceiling would require the exercise of substantially less legislativestyle policy judgment than the decision of what programs to cut and by how much or the decision of what taxes to raise and by how much. That judgment reasonably closely parallels the sort of judgment courts must make in deciding whether a statute can fairly bear a proposed narrowing construction. Indeed, if anything, the argument that ignoring the debt ceiling usurps less legislative power than either cutting spending or raising taxes strikes us as more decisive than common arguments for adopting or rejecting a narrowing construction of a statute challenged as unconstitutional. More broadly, here, as elsewhere, an admittedly mushy multifactor test can still yield clear answers in cases far from the margins.

One may also encounter mushiness at the threshold. Many constitutional clauses and tests have fuzzy borders, and so, at least prior to a definitive resolution of the issue, it will not always be clear whether some proposed course of action would be unconstitutional. Faced with a choice between a merely arguably unconstitutional option and a clearly unconstitutional option, the possibility that the former course might turn out to be constitutional gives the president (or other actor) a powerful reason for choosing it over the clearly unconstitutional course. For simplicity, our examples assume a choice among options that are all clearly unconstitutional, but one could apply the same analysis if one or more options is merely arguably unconstitutional, placing an appropriate-sized thumb on the scale in favor of the option that might turn out to be constitutional. For the same reasons we have not attempted to reduce the comparison between clearly unconstitutional options to an algorithm, we make no such attempt where one or more options is only arguably unconstitutional.

\section{Minimize Sub-Constitutional Harm}

Another lesson that emerges from the debt ceiling crisis is that decisionmakers ought to try to minimize sub-constitutional harm as well as constitutional harm. Here, "sub-constitutional" harm refers to real harm-economic hardship or even lost lives-but not necessarily harm that amounts to a constitutional violation. The difference between the two madman scenarios sheds light on what we mean. In both instances, option (2) involved the unconstitutional usurpation by the president of

requirements." (omission in original) (quoting Virginia v. Am. Booksellers Ass'n, 484 U.S. $383,397(1988)))$. 
the power of Congress to commit the nation to war. But part of what made option (2) worse in the first scenario than in the second scenario was a judgment about consequences: It would be worse to use nuclear weapons against Iran than to provide air support for Libyan rebels because the likely consequences of using nuclear weapons against Iranthe deaths of millions of Iranian civilians and the possibility of nuclear retaliation against the United States or its allies-would be worse than the consequences of supporting Libyan rebels-at best displacing a dictator with democracy and at worst a mostly contained civil war.

But in saying that differences between the consequences of unconstitutional options matter, we do not mean that consequences are all that matters. The president's decision to ignore the debt ceiling, we have emphasized, would usurp less legislative power-and would thus be less unconstitutional - than a president's decision to decide which spending programs to cut and by how much or which taxes to raise and by how much. Ignoring the debt ceiling would continue to be less unconstitutional than either of the other unilateral presidential actions even if it appeared that, on balance, one of these other options would lead to somewhat better consequences. Perhaps the damage to the economy from the government having to pay higher rates of interest on Presidential bonds could be expected to be greater than the damage to the economy from the expected loss of confidence that would arise from unilateral presidential action cutting spending or raising taxes. Even so, we think that ignoring the debt ceiling would be the less unconstitutional option-unless the differences in projected consequences were reckoned in orders of magnitude. Put differently, taking the Constitution seriously—and rejecting the "all bets are off" approach-means giving priority to minimizing constitutional harm, while treating as secondary the principle that sub-constitutional harm ought to be minimized.

To be sure, giving priority to the avoidance of constitutional harm does not mean giving it absolute priority. If the consequences of following what would otherwise be the least unconstitutional of several unconstitutional paths would be truly catastrophic, then we think that government officials would be justified in choosing a somewhat more unconstitutional option that did not lead to catastrophe. With this caveat, our view is analogous to what moral philosophers call threshold deontology: One treats certain rules as impervious to arguments for being overridden by consequentialist considerations, unless the expected adverse consequences rise above a threshold of moral catastrophe. ${ }^{197}$ For example, a

197. See, e.g., Larry Alexander, Deontology at the Threshold, 37 San Diego L. Rev. 893, 894 (2000) [hereinafter Alexander, Deontology] ("There are some acts that are morally wrong despite producing a net positive balance of consequences; but if the positive balance of consequences becomes sufficiently great...then one is morally permitted, and perhaps required, to engage in those acts that are otherwise morally prohibited."); Michael S. Moore, Torture and the Balance of Evils, 23 Isr. L. Rev. 280, 32732 (1989) (articulating theory and structure of threshold deontology). In drawing an 
threshold deontologist might say that torture is morally impermissible to save a life or even ten lives but that it is permissible to save a million lives. ${ }^{198}$ Likewise here, a president should not choose to cut spending or raise taxes rather than ignore the debt ceiling in order to save a few million dollars in GDP, but he could make that choice to avert a substantial chance of a worldwide depression.

The principle of catastrophe avoidance should also apply even in circumstances in which the president or some other political actor has available at least one technically constitutional option. For parallelism we shall call our view of this question threshold constitutionality. Just as threshold deontologists are deontologists below a threshold of catastrophic harm, threshold constitutionalists favor compliance with the Constitution below a threshold of catastrophic harm.

We can illustrate threshold constitutionality by reference to Professor Balkin's "jumbo coins" proposal. Recall that Balkin argued that, even if Congress had failed to raise the debt ceiling, the President could have avoided acting unconstitutionally if he had instructed the Treasury Department to mint two one-trillion-dollar platinum coins to be deposited in the government account with the Federal Reserve, thereby creating an additional two-trillion dollars for the government to spend on its obligations. ${ }^{199}$

We note two objections to the jumbo coins proposal. First, the very act of minting trillion-dollar coins looks so cartoonish and desperate that it could undermine faith in the government's ability to repay its obligations, and for that reason it might be understood as a violation of Section 4 of the Fourteenth Amendment. ${ }^{200}$ A public that observes the federal government resorting to exotic gimmicks like minting trillion-dollar coins has reason to worry that public debt may go unpaid. Second, even if one takes a narrower view of Section 4-so that nothing short of actual default on obligations counts as a violation-the jumbo coins proposal would likely spook the markets, leading lenders to demand a very high rate of interest.

But is that second factor a legitimate consideration absent constitutional necessity? Suppose that the jumbo coins would not actually violate

analogy to threshold deontology, this Article expresses no position on whether threshold deontology, straight utilitarianism, straight deontology, or some other moral view (such as virtue ethics) is generally correct.

198. Compare Alexander, Deontology, supra note 197, at 898-901 (“[T] he most plausible account of a deontological threshold would consider both the number of persons at which the interests at stake justify overriding negative duties ... and the number of persons at which the interests at stake justify imposing affirmative duties ...."), with Moore, supra note 197, at 314-15 ("The moral answer ... must be ... [y] ou cannot torture or kill the innocent, even to achieve what are admittedly good consequences....”).

199. Balkin, Ways to Bypass, supra note 22.

200. See supra note 94 and accompanying text. 
Section 4 of the Fourteenth Amendment or any other constitutional provision. Even if minting the jumbo coins would have terrible consequences, would the president nonetheless be obligated to prefer the jumbo coin option to one of the unconstitutional options (such as ignoring the debt ceiling, cutting spending, or raising taxes)? Is there some requirement that a president (or other government official) must exhaust his constitutional options, no matter how disastrous, before he may even consider unconstitutional options? More generally, is threshold constitutionality justified? We think it is, although we also think that most of our analysis should be relevant to those who disagree.

Disagreement with threshold constitutionality might lead to an absolutist position. No matter how high the cost of compliance, the absolutist says that government officials simply may not violate the Constitution if they have any constitutional options. In this view, a nondefeasible constitutional provision or doctrine-like the separation of powers-is just that: completely nondefeasible. ${ }^{201}$

For the absolutist, choices among truly unconstitutional options will rarely arise, because any constitutional option-no matter how outlandish or tragic - will have to be given priority. ${ }^{202}$ Under this view, the president must sacrifice his life to the gun-wielding madman rather than choose one of the two unconstitutional options; he must also choose the jumbo coins option (or some equally outlandish but constitutionally valid scheme) if he concludes that it is constitutional, even if doing so would bring financial ruin that could have been avoided by one of the other unconstitutional options.

We think that the absolutist position for rejecting threshold constitutionality is unjustified for the same sorts of reasons that have been advanced in favor of threshold deontology and other pluralist moral views. ${ }^{203}$ Where a deontological purist would avoid telling a lie even at the cost of ending the world, we would not. Averting catastrophe warrants violating the Constitution.

That is not to deny that there is something to be said for the absolutist view. One might worry that if constitutional provisions are not deemed

201. See Craig R. Ducat, Constitutional Interpretation 76-80 (9th ed. 2009) (discussing constitutional absolutism and the roles rules and principles play in determining constitutionality of laws).

202. Just a few years before his "all the laws but one" speech, Abraham Lincoln appeared to endorse absolutism, albeit in a context that did not involve a threat to the Union. See Abraham Lincoln, Address at Cooper Institute, New York City (Feb. 27, 1860), in 3 Collected Works of Lincoln, supra note 156, at 522, 531 ("No one who has sworn to support the Constitution, can conscientiously vote for what he understands to be an unconstitutional measure, however expedient he may think it ....").

203. For a useful exposition of moral pluralism within the "virtue ethics" tradition traceable to Aristotle, see Gregory S. Alexander \& Eduardo M. Peñalver, An Introduction to Property Theory 97-101 (2012) (exploring how moral pluralist theories respond to problem of value incommensurability). 
inviolable, government officials will attach too little weight to them. The absolutist stance is suboptimal, in this approach, but less suboptimal than any approach that rejects absolute prohibitions. To continue the torture analogy, if the law purports to permit torture but only in the tickingbomb scenario, one might worry that the government will start hearing bombs ticking everywhere. ${ }^{204}$ An absolute rule deliberately overshoots the mark to avoid the worse sin of undershooting the mark. ${ }^{205}$

Notwithstanding the foregoing logic, one might conclude-as we do in the present context-that there are both principled and pragmatic problems with a deliberately overinclusive absolute prohibition. If one thinks that catastrophes ought to be averted, then, as a matter of principle, there is something dishonest about pretending that one takes an absolutist stance. Moreover, as a practical matter, it is hardly clear that the absolutist prohibition does not lead to overdeterrence. By hypothesis, threshold constitutionality only permits resort to unconstitutional action to avert a catastrophe, and so adopting the absolutist position risks bringing about catastrophes. At a minimum, before adopting the absolutist position, one ought to consider the alternatives.

One alternative would be a version of threshold constitutionality that incorporates catastrophe avoidance into considerations of constitutionality. In this approach, catastrophe avoidance operates within constitutional law to treat an otherwise unconstitutional course of action as constitutional so long as it is the least unconstitutional of the possible courses of action that avoid catastrophic harm. ${ }^{206}$ In the context of the debt ceiling crisis one might say something like this: We all thought that the separation of powers was nondefeasible, but we have now encountered a case that leads us to conclude otherwise. Thus, the rule that says that the president may not borrow money (or tax or cut spending) without congressional authorization should be reformulated to say that the president may not borrow money (or tax or cut spending) without congressional authorization, unless doing so is necessary to avert a catastrophe. Call this the conflict suppression version of threshold constitutionality: In this approach, the Constitution accommodates the need to avoid catastrophes by

204. Worse yet, the government may deliberately aggravate situations in order to justify the use of torture. See Alexander, Deontology, supra note 197, at 902-04 (describing possibility of intentionally increasing danger in order to reach deontological threshold).

205. In the torture context, Oren Gross has argued that an absolute prohibition is optimal because it will lead to just the right amount of torture-almost none. Oren Gross, Are Torture Warrants Warranted? Pragmatic Absolutism and Official Disobedience, 88 Minn. L. Rev. 1481, 1486-87, 1501-11 (2004).

206. For similar approaches and critiques, see Richard A. Posner, Not a Suicide Pact: The Constitution in a Time of National Emergency 157-58 (2006) (noting "law of necessity" should be "understood not as law but as the trumping of law by necessity"); Benjamin A. Kleinerman, 9/11, the Liberty/Security Balance, and the Separation of Powers, Crim. Just. Ethics, Winter/Spring 2007, at 59, 62 (reviewing Posner, supra). 
authorizing what might otherwise be constitutional violations. ${ }^{207}$ Slogans like "the Constitution is not a suicide pact" reflect the conflict suppression sentiment. ${ }^{208}$

Presidents (and other elected officials) should find conflict suppression attractive because it enables them to deny that they are ever deliberately taking actions that violate the Constitution. And indeed, conflict suppression has deep roots in our constitutional culture-so deep that courts and political actors virtually never even acknowledge that constitutional duties may conflict.

Consider a case that might have been a counterexample. Nebraska Press Ass'n v. Stuart ${ }^{209}$ involved at least the potential for a conflict between the First Amendment right of the press to report fully on a criminal trial and the Sixth Amendment right of the defendant to a fair trial untainted by pretrial publicity. Speaking for the Court in that case, Chief Justice Burger began by appearing to recognize a textual conflict. He wrote, "The authors of the Bill of Rights did not undertake to assign priorities as between First Amendment and Sixth Amendment rights, ranking one as superior to the other., ${ }^{210} \mathrm{He}$ then disavowed any judicial power to "assign[] to one [right] priority over the other." resolved the case.

How? By construing the outer bounds of the First and Sixth Amendments so that neither infringed the other. The Court held that gag orders may be used to override the First Amendment right to freedom of speech and of the press where doing so is essential to ensuring a fair trial ${ }^{212}$ - thus favoring the Sixth Amendment over the First Amendment if push comes to shove-but the Court also held that in the particular case there had not been a sufficient showing that muzzling the press was necessary to protect the defendant's right to a fair trial. ${ }^{213}$

207. See, e.g., Terminiello v. City of Chicago, 337 U.S. 1, 37 (1949) (Jackson, J., dissenting) ("There is danger that, if the Court does not temper its doctrinaire logic with a little practical wisdom, it will convert the constitutional Bill of Rights into a suicide pact.”).

208. Courts and commentators frequently voice this sentiment in the national security context. See, e.g., Kennedy v. Mendoza-Martinez, 372 U.S. 144, 160 (1963) ("[W] hile the Constitution protects against invasions of individual rights, it is not a suicide pact."); Peter Brandon Bayer, Sacrifice and Sacred Honor: Why the Constitution Is a "Suicide Pact", 20 Wm. \& Mary Bill Rts. J. 287, 289 (2011) (discussing self-defeating characteristics of "true constitution"); see also David Corn, The "Suicide Pact" Mystery: Who Coined the Phrase? Justice Goldberg or Justice Jackson?, Slate (Jan. 4, 2002, 11:04 AM), http://www.slate.com/articles/news_and_politics/politics/2002/01/the_suicide_ pact_mystery.html (on file with the Columbia Law Review) (attributing coining of phrase to Justice Jackson).

209. 427 U.S. 539 (1976).

210. Id. at 561 .

211. Id.

212. Id. at 562,570 .

213. Id. at 567-69. 
Although we agree with the substantive result of Nebraska Press Ass'n, we regard the Court's claim to have avoided prioritizing rights as highly formalistic. The Court said, in substance if not in form, that the fair trial right is more important than the free press right, at least in a case of unavoidable conflict. But the Court somehow managed to persuade itself that conflict was avoidable. ${ }^{214}$

What were the alternatives? An absolutist of the sort who would insist on the Treasury minting jumbo coins at the cost of crashing the global economy might say that the conflict in Nebraska Press Ass' $n$ was avoidable. The defendant in that case was accused of murdering six people, but the Constitution does not require that every murderer be punished. If it were impossible for the defendant to receive a fair trial while at the same time honoring the freedom of the press, an absolutist would say that the constitutionally required solution is to simply dismiss the indictment.

The dismissal solution might take as its model the exclusionary rule in criminal procedure, which bars the admission of evidence obtained in violation of the Fourth or Fifth Amendment. ${ }^{215}$ If there is insufficient other evidence for a jury to find a defendant guilty beyond a reasonable doubt, then the exclusionary rule effectively requires dismissal of an indictment. ${ }^{216}$ If that rule obtains for the Fourth and Fifth Amendments, the absolutist might ask, why not for the First and Sixth Amendments?

The comparison is suggestive but, we think, ultimately unpersuasive, as the Supreme Court's own exclusionary rule jurisprudence indicates. In the post-Warren Court era, the case law has substantially whittled away at the exclusionary rule, recognizing numerous exceptions where the

214. Id. at 570. A federal appeals court once announced that the Fifth Amendment right to due process would conflict with, and should prevail over, the Seventh Amendment right to a civil jury trial if a case were too complex and technical for laypersons to resolve as jurors. In re Japanese Elec. Prods. Antitrust Litig., 631 F.2d 1069, 1084-86 (3d Cir. 1980). That court cited Nebraska Press Ass'n for the proposition that when two constitutional requirements conflict, the court should balance the constitutionally protected interests to produce an accommodation. Id. at 1084. However, other appeals courts have rejected the notion that the jury trial right must yield because of complexity. See, e.g., SRI Int'l v. Matsushita Elec. Corp. of Am., 775 F.2d 1107, 1128-30 (Fed. Cir. 1985) ("Elbowing to one side the Seventh Amendment, and the compelling social and democratic (much less constitutional) bases for its existence, would be at best an unseemly judicial exercise.”); In re U.S. Fin. Sec. Litig., 609 F.2d 411, 432 (9th Cir. 1979) (holding "there is no complexity exception to the Seventh Amendment right to jury trial in civil cases").

215. See, e.g., Oregon v. Elstad, 470 U.S. 298, 306-07 (1985) (explaining interplay between Fifth Amendment, Miranda warnings, and remedy of exclusion for Miranda violations); Mapp v. Ohio, 367 U.S. 643, 649-50 (1961) (holding evidence obtained in violation of Fourth Amendment may not be used in state criminal prosecutions).

216. See United States v. Leon, 468 U.S. 897, 907 n.6 (1984) (discussing studies on effect of exclusionary rule on disposition of felony arrests). 
Justices have found that application of the rule is not cost-justified. ${ }^{217}$ We think that these exceptions show that the exclusionary rule has not been understood in absolutist terms. Although early cases invoking a judicial integrity rationale for the exclusionary rule could be understood in absolutist terms, the modern doctrine-which rationalizes the exclusionary rule as a deterrent to illegal police investigation ${ }^{218}$ - shows the Court carefully calculating costs and benefits. Put simply, we do not have a criminal procedure doctrine that instructs courts to exclude unlawfully obtained evidence even when the results would be catastrophic. We have more nearly the opposite: a set of doctrines that seek to limit the damage from strict insistence on the observance of constitutional rights.

Indeed, even those jurists who have resisted the erosion of the exclusionary rule need not be understood as constitutional absolutists. Rather, it may make more sense to understand their view as one that simply strikes a different balance from the balance that their tougher-on-crime colleagues strike. ${ }^{219}$ For the would-be strict enforcers of the exclusionary rule, the long-term damage that comes from admitting unlawfully obtained evidence may seem greater than the harm that comes from occasionally permitting a guilty defendant to go free..$^{220}$

If a weighing of costs and benefits underlies the Justices' avoidance of absolutism by commonly rejecting the application of the exclusionary rule as a remedy for acknowledged constitutional violations, no such open weighing is visible in their efforts to deal with circumstances in which two rights conflict. The Supreme Court's discussion of the options

217. See, e.g., Jennifer E. Laurin, Trawling for Herring: Lessons in Doctrinal Borrowing and Convergence, 111 Colum. L. Rev. 670, 691-94 (2011) (discussing development of cost-benefit analysis for exclusionary rule and cases in which Supreme Court has found application of rule not cost-justified); Potter Stewart, The Road to Mapp v. Ohio and Beyond: The Origins, Development and Future of the Exclusionary Rule in Search-and-Seizure Cases, 83 Colum. L. Rev. 1365, 1399-1404 (1983) (arguing against "good faith" exception to exclusionary rule within deterrence framework).

218. See Hudson v. Michigan, 547 U.S. 586, 591-92 (2006) (noting modern exclusionary rule applies narrowly, only to cases with deterrence value); Peter Arenella, Rethinking the Functions of Criminal Procedure: The Warren and Burger Courts' Competing Ideologies, 72 Geo. L.J. 185, 192-93, 236-38 (1983) ("The Court has focused primarily on whether the future deterrent benefits secured by applying the exclusionary rule outweigh its present tangible costs to reliable guilt-determination."); Thomas Y. Davies, The Supreme Court Giveth and the Supreme Court Taketh Away: The Century of Fourth Amendment "Search and Seizure" Doctrine, 100 J. Crim. L. \& Criminology 933, 990-91, 997-1000, 1006-10 (2010) (tracing Supreme Court's embrace and affirmance of deterrence rationale).

219. Cf. Stewart, supra note 217, at 1404 ("I have suggested that the exclusionary rule is a constitutionally mandated remedy, necessary to enforce the fourth and fourteenth amendments, and that proposals to modify the rule must preserve an effective remedy.").

220. See, e.g., John P. Gross, Dangerous Criminals, the Search for the Truth and Effective Law Enforcement: How the Supreme Court Overestimates the Social Costs of the Exclusionary Rule, 51 Santa Clara L. Rev. 545, 570-71 (2011) (arguing Supreme Court overestimates costs of exclusionary rule, including danger from freeing guilty defendants). 
on offer in Nebraska Press Ass' $n^{221}$ was typical for American jurisprudence in its failure to recognize interclausal conflict, and in that respect, the United States is an outlier. In most other constitutional democracies, a court (or other constitutional interpreter) would view a conflict between two rights (or any two constitutional provisions) as calling for adjudication. ${ }^{222}$ A court (or other actor) would ask which right should prevail in the particular circumstances, by giving priority to one or the other right, by balancing the competing interests at stake, or by some other method that openly acknowledges the conflict. The following figure illustrates the difference between conflict suppression of the Nebraska Press Ass'n sort and European- or Canadian-style conflict resolution.

\section{Conflict Suppression}

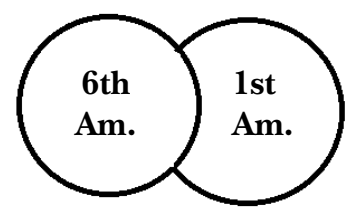

Conflict Acknowledgment

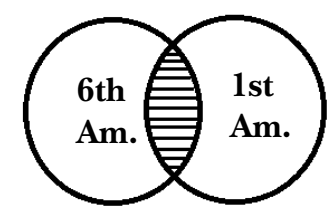

In the conflict-suppression approach, the prevailing right (in Nebraska Press Ass'n, the Sixth Amendment fair trial right) eats into area that the other right (the First Amendment free press right) would otherwise occupy. By contrast, in the conflict-acknowledgment approach, the constitutional decisionmaker recognizes that the two rights overlap (as represented by the shaded area) but then decides that one rather than the other right prevails in that area of overlap.

The Supreme Court's interpretation of the religion clauses of the First Amendment also illustrates American constitutional law's prefer-

221. See supra notes 209-214 and accompanying text.

222. See Jamal Greene, The Rule of Law as a Law of Standards, 99 Geo. L.J. 1289, 1291 (2011) (" $[\mathrm{M}]$ any of the world's most respected constitutional courts, including the courts of Canada, Germany, Israel, India, and South Africa, in addition to the European Court of Human Rights and the European Court of Justice, incorporate balancing into forms of proportionality analysis.”). For a careful exposition of the stages of balancing as employed in modern rights jurisprudence by one of the world's most important jurists of the last quarter century, see generally Aharon Barak, Proportionality: Constitutional Rights and Their Limitations (2012). 
ence for conflict suppression over conflict acknowledgment. The courts could say that when a person of faith seeks funding for religious activity or an exemption from a generally applicable law, her claim presents a conflict between free exercise and establishment: On the one hand, denial of the exemption or funding will infringe her religion; on the other hand, granting the exemption or funding may show favoritism towards religion in general or her particular religion. Under such a formulation, courts would be required to resolve the conflict between the free exercise interests and the establishment interests. But in such cases, the Supreme Court has gone out of its way to avoid construing the relevant provisions as overlapping. Indeed, the cases recognize a kind of no man's land of legislative freedom between the religion Clausespermitting "'room for play in the joints' between" free exercise and establishment. ${ }^{223}$

To be sure, the results of conflict acknowledgment and conflict suppression may often be the same. Even the processes of reaching those results may be similar. However, the conflict acknowledgment approach has the comparative virtue of transparency: Courts (and other actors) openly admit both that there is a conflict between the constitutional provisions and that they are favoring one rather than the other approach.

We do not mean to suggest that conflict acknowledgment is a perfect model for the choice we seek to understand in this Article, because we are interested in how to decide among unconstitutional options. Courts that acknowledge interclausal conflict typically say that after the balancing is completed, the course of action that vindicates the winning right (or other provision) is constitutionally permissible (or, in the case of a multinational human rights treaty such as the European Convention on Human Rights, permitted by the treaty). ${ }^{224}$ Nonetheless, conflict acknowledgment is still a better model for the choice among unconstitutional options than is conflict suppression because the former makes the element of choice apparent.

Conflict-acknowledging approaches illustrate what Michael Walzer has termed the problem of "dirty hands." ${ }^{225}$ The core idea is that political actors and others sometimes face "tragic choices" in which any choice they make (including the choice to do nothing) will be a choice to do evil. (The William Styron novel Sophie's Choice - in which Nazis force a woman to choose which of her two children to sacrifice in order that the

223. Locke v. Davey, 540 U.S. 712, 718 (2004) (quoting Walz v. Tax Comm'n, 397 U.S. 664,669 (1970)).

224. See, e.g., I.A. v. Turkey, 2005-VIII Eur. Ct. H.R. 249, 258 (holding Turkish court that fined author of book offensive to Islam did not violate European Convention on Human Rights due to "pressing social need").

225. Michael Walzer, Political Action: The Problem of Dirty Hands, in War and Moral Responsibility 62 (Marshall Cohen et al. eds., 1974). 
other may be spared-presents a dramatic example in the personal realm. ${ }^{226}$ ) They have reason to choose the least bad option but doing so remains wrongful. ${ }^{227}$ In the legal academic literature, Oren Gross has built on the insights of Walzer and others to develop a set of principles for the legal system to evaluate extra-constitutional decisionmaking. ${ }^{228}$

We take no position here on the exact approaches proposed by Walzer, Gross, or anyone else. Our point in invoking their work is much more basic: Whether we like it or not, life sometimes presents tragic choices in which there are no good options, and likewise with the law. Faced with a constitutional tragic choice, insistence on compliance with constitutional rules will be futile (if there are truly no permissible options), catastrophic (if there are technically permissible options that will lead to a catastrophe but one insists on absolute adherence to such rules anyway), or question-begging (if one uses a conflict suppression strategy).

Summarizing the principles that have emerged in this section, we would emphasize three points: (1) after giving priority to minimizing constitutional harm, legal actors finding themselves with no constitutional options should attempt to minimize sub-constitutional harm; but (2) minimizing constitutional harm should not be given absolute priority, so that where sub-constitutional harm exceeds a catastrophic threshold, legal actors may sometimes even be justified in choosing an unconstitutional course over a constitutional one; and (3) in choosing among unconstitutional options, it is better to acknowledge conflict than to recategorize constitutional violations in ways that suppress or disguise conflict.

\section{Preserve, to the Extent Possible, the Ability To Undo or Remedy Constitutional Violations}

Our final general principle states that government officials choosing among unconstitutional options should preserve, to the extent possible, their own ability and the ability of other actors to undo or remedy constitutional violations. Often the choice among unconstitutional options will be controversial. Indeed, sometimes it will not even be clear that one or another proposed course of action really is unconstitutional. Accord-

226. William Styron, Sophie's Choice (Modern Library 1998) (1979).

227. As Gregory Alexander and Eduardo Peñalver note, people who think that all normative decisions can be reduced to a single currency (such as aggregate utility) have difficulty "accounting for the notion that moral choice sometimes involves the need to act even in the face of irreconcilable conflict among values." Alexander \& Peñalver, supra note 203, at 99. One could analogize the moral monists that Alexander and Peñalver critique to those constitutional interpreters who favor suppressing conflict among constitutional clauses and doctrines.

228. See Oren Gross, Chaos and Rules: Should Responses to Violent Crises Always Be Constitutional?, 112 Yale L.J. 1011, 1105 (2003) (invoking Walzer and Max Weber). 
ingly, such controversy should weigh in favor of some proposed choice that is readily reversible.

To the extent that a choice among putatively unconstitutional options is controversial because of a contest over constitutional meaning, political actors ought to strive to ensure that their favored option permits expeditious judicial review. This factor arguably cuts against our own prioritization in the debt ceiling trilemma. Recall that by our lights, the president's two worst unconstitutional options were unilaterally cutting spending and unilaterally raising taxes, while his least bad unconstitutional option was to issue Presidential bonds. Yet cutting spending or raising taxes would likely lead to justiciable cases, whereas issuing Presidential bonds might not.

A decision to cut spending would quickly lead to a lawsuit by a person or entity legally entitled to receive funding absent the cut. ${ }^{229}$ Likewise, a decision to raise taxes would likely lead to a lawsuit by some party whose resulting tax liability increased. To be sure, given the AntiInjunction Act, a taxpayer could not seek to enjoin the assessment or collection of his increased taxes, but once he paid the tax, he could sue for a refund in the Tax Court, with review in the Article III courts, including the potential for certiorari review by the Supreme Court to follow. ${ }^{230}$ But a lawsuit challenging the president's decision to issue Presidential bonds would not necessarily lead to litigation.

Would anyone suffer the sort of concrete and particularized injury needed to authorize Article III standing as a consequence of the issuance of Presidential bonds? If the government were to fail to pay interest or principal to the holder of a Presidential bond, then the bondholder would clearly suffer injury. But what if the government does not default?

One can imagine litigation that would indirectly raise the question of the validity of the Presidential bonds. Suppose that state law or the contractual terms governing some investment fund provide that the fund may only hold "legal" bonds and securities. Suppose further that the fund manager adds Presidential bonds to the fund's portfolio. A state official or fund beneficiary might then sue the manager of the fund for violating state law or the contractual terms, and the outcome of the action would depend on the legality of the underlying Presidential bonds. ${ }^{231}$ But it is not obvious that such a dispute would arise quickly

229. Clinton v. City of New York is straightforward precedent. The City of New York successfully challenged spending cuts that President Clinton made under the Line Item Veto Act. 524 U.S. 417 (1998).

230. 26 U.S.C. $\$ 7421$ (a) (2006); cf. Flora v. United States, 357 U.S. 63, 75 (1958) (discussing settled principle of "pay first and litigate later").

231. Such a lawsuit might fall within the statutorily authorized original jurisdiction of the federal courts, see Smith v. Kan. City Title \& Trust Co., 255 U.S. 180, 199 (1921) (upholding statutory federal question jurisdiction where state law restricted investments to 
enough to present the issue of the bonds' validity for expeditious judicial resolution.

Are there other mechanisms by which the Presidential bonds' validity could come before the courts? Perhaps holders of other government debt (for example, Treasury bonds) might worry that by increasing the total debt, Presidential bonds make it less likely that they will receive payment-much in the way that the holder of a first mortgage on a home might worry that the homeowner's further indebtedness to new lenders puts the initial loan at greater risk. Yet as we explained above, the principles of default risk applicable to private parties do not apply to a sovereign lending in its own currency. ${ }^{232}$ Moreover, the whole point of the Presidential bonds would be to prevent default on existing obligations, and so it seems highly speculative to say that the Presidential bonds increase default risk. In any event, even if the Presidential bonds did increase default risk somewhat, the increased risk of a default in the indefinite future might not count as the sort of "imminent" injury that the Court's cases require for Article III standing. ${ }^{233}$ Thus, it appears that a decision to issue Presidential bonds would be substantially more difficult to challenge in court than a presidential decision to cut spending or raise taxes.

Does that fact lead us to reassess our priority among the elements of the trilemma? In a word, no. It is true that judicial reviewability counts for something, but here the reason why there would be no direct judicial review of the Presidential bonds is a double-edged sword that is much sharper on its other edge. If no one has standing to challenge the Presidential bonds directly, that is because no one is directly injured by them. In the overall cost-benefit analysis, surely the fact that Presidential bonds cause no concrete and imminent harm counts mostly in their favor, not against them.

To be clear, we do not claim that Presidential bonds are necessarily harmless. Relative to spending cuts and tax increases, Presidential bonds increase the national debt, which could have adverse long-term consequences. But spending cuts and tax increases also could have adverse long-term consequences, and, in addition, they cause immediate direct injuries in a way that Presidential bonds mostly do not. How one nets out the various short-term and long-term costs and benefits of each possible course of action is a very complicated question. Our point for now is simply that the absence of any direct concrete and imminent harm to an

"legal securities only"), but even if not, the issue could reach the United States Supreme Court in a case filed originally in state court.

232. See supra text accompanying notes 80-83.

233. See Summers v. Earth Island Inst., 555 U.S. 488, 492-95 (2009) (repeatedly reciting requirement that plaintiff seeking injunctive relief against government must allege imminent concrete injury). 
identifiable party probably counts in favor of Presidential bonds by an amount that outweighs the cost in forgone or delayed judicial review.

In any event, judicial review is no panacea. A court could decide a multi-lemma case in a way that makes clear that one course of action is preferred. For example, a court might decide that the president has the unilateral power to cut spending after all. But assuming a case in which there truly are no (non-catastrophic) constitutional options, a reviewing court does not face the same decision that a political actor does.

For concreteness, suppose that faced with the trilemma, the president chooses to cut spending and that a canceled beneficiary challenges the cuts. A reviewing court cannot simply rule that the spending cut was unconstitutional because, by hypothesis, anything the president might have done would have been unconstitutional. But as we have unpacked the president's trilemma, selecting a course of action requires a delicate blend of constitutional and policy analysis. We can well imagine that the best course for the president in resolving the trilemma would be to issue Presidential bonds but that the courts ought to uphold the president's selection of any of the horns of the trilemma as a reasonable exercise of his discretion. We would therefore sympathize with a holding that a complaint charging the president (or other political actor) with choosing the wrong unconstitutional option ought to be nonjusticiable. In this view, the president does not face a naked policy choice in choosing among unconstitutional options; the relevant constitutional and policy guideposts leave him with sufficient discretion to render the matter a political question.

Whether or not a particular choice among unconstitutional options would lead to a justiciable case or controversy, political actors ought to try to take actions that can be undone by other political actors. That is especially true where-as in the debt ceiling trilemma-the core concern is separation of powers. ${ }^{234}$ Because the president, no matter what he does, will end up stepping on the toes of Congress, he ought to ensure that Congress can specify which toes it wants stepped on (or conversely, which toes it most wants to avoid being stepped on).

We argued in Part II that the prior choices of Congress indicate that it placed a higher priority on having its decisions about taxing and spending respected than about having the borrowing limit respected. That conclusion was substantially based on the detailed political tradeoffs that go into taxing and spending laws, by contrast with the simple selection of a number for the debt ceiling. ${ }^{235}$ The same factors lead us to conclude that a presidential decision to spend or tax unilaterally would be more disruptive of the legal status quo than a decision to issue

\footnotetext{
234. See Mistretta v. United States, 488 U.S. 361, 382 (1989) (“[C]oncern of encroachment and aggrandizement... has animated our separation-of-powers jurisprudence ....").

235. See supra text accompanying notes 140-143.
} 
Presidential bonds, and thus, as a practical matter, substantially more difficult for Congress to undo. Put most simply, because a presidential decision to cut spending or raise taxes unilaterally usurps substantially more legislative power than a decision to issue Presidential bonds, cutting spending or raising taxes will generally be stickier. ${ }^{236}$ If judicial review of a presidential decision to cut spending or raise taxes is more likely to occur than judicial review of the decision to issue Presidential bonds, effective congressional review of the Presidential bonds is more likely than effective congressional review of unilateral spending cuts or tax increases. And where, as in the debt crisis case, the core concern is separation of powers, preserving the opportunity for effective congressional review strikes us as more important than facilitating judicial review.

\section{CONCLUSION}

The debt ceiling crisis of 2011 nearly presented President Obama with a trilemma of unconstitutional options. Should he or a future president ever squarely face such a trilemma, he would have no good choices and certainly no good constitutional choices. But choose the president must. He should do so in a manner that minimizes the unconstitutional assumption of power, minimizes sub-constitutional harm, and maximally preserves the ability of other actors to undo or remedy constitutional violations. In the debt ceiling context, given the balance of constitutional, practical, and prudential considerations, the least unconstitutional choice would be for the president to continue to issue debt, in the amounts authorized by the duly enacted budget of the United States.

236. See supra text accompanying notes 144-145. We acknowledge that there is a sense in which issuing Presidential bonds would be stickier than either unilaterally raising taxes or cutting spending. The bonds (if deemed valid) would create a property interest, which Congress would be constitutionally obligated to respect. Cf. supra text accompanying note 69 . By contrast, taxes raised by the president could be subsequently cut by Congress and spending cut by the president could be restored by Congress without violating the Constitution. Thus, when we say that Congress can undo a president's unilateral borrowing, we do not mean that Congress could default on outstanding bonds. We are measuring stickiness in a practical political sense rather than a strictly legal sense. See Eskridge \& Ferejohn, supra note 144, at 528-33 (modeling interactions between president and Congress as iterative game). 